\title{
New species and additional records of Lomechusini from the Palaearctic region, primarily from China (Coleoptera: Staphylinidae: Aleocharinae)
}

With 81 figures and 2 maps

VOLKER ASSING ${ }^{1}$

${ }^{1}$ Gabelsbergerstraße 2, 30163 Hannover, Germany. - vassing.hann@t-online.de Published on 2015-12-21

\section{Summary}

Six species of Lomechusini from China and North India are (re-)described and illustrated: Drusilla yunnanensis PACE, 1993; D. watanabei Maruyama \& Kishimoto, 2002; D. flagellata spec. nov. (China: Yunnan); D. palata spec. nov. (China: Yunnan); Amaurodera angularis spec. nov. (North India: West Bengal); Lomechusoides penicillatus spec. nov. (China: Gansu). Two synonymies are proposed: Drusilla canaliculata $($ FABRICIUs, 1787) $=$ D. puncticollis MotschulskY, 1845, syn. nov.; Amaurodera smetanai PACE, 1992 = A. yaoana PACE, 1992, syn. nov. Additional records of 29 previously described species of Drusilla Leach, 1819, Pella Stephens, 1835, Amaurodera Fauvel, 1905, Tetrabothrus Bernhauer, 1915, and Lomechusoides Toтtenнам, 1939 are reported from the Palaearctic region, primarily from China, among them several new country records and the first record of Pella lugens (Gravenhorst, 1802) from the East Palaearctic. The previously unknown aedeagus of Pella reuteri Assing, 2008, the previously unknown female sexual characters of Amaurodera ilamica Assing, 2005, and the primary sexual characters of several Pella species recorded from China are illustrated. The distributions of the Drusilla species currently known from China are illustrated.

\section{Key words}

Coleoptera, Staphylinidae, Aleocharinae, Drusilla, Pella, Amaurodera, Lomechusoides, East Palaearctic region, China, taxonomy, new species, new synonymy, additional records, distribution maps

\section{Zusammenfassung}

Sechs Arten der Tribus Lomechusini aus China werden beschrieben bzw. redeskribiert und abgebildet: Drusilla yunnanensis Pace, 1993; D. watanabei Maruyama \& Kishimoto, 2002; D. flagellata spec. nov. (China: Yunnan); D. palata spec. nov. (China: Yunnan); Amaurodera angularis spec. nov. (Nordindien: Westbengalen); Lomechusoides penicillatus spec. nov. (China: Gansu). Zwei Namen werden synonymisiert: Drusilla canaliculata (FABricius, 1787) $=$ D. puncticollis Motschulsky, 1845, syn. nov.; Amaurodera smetanai PACE, 1992 = A. yaoana PACE, 1992, syn. nov. Weitere Nachweise von 29 Arten der Gattungen Drusilla Leach, 1819, Pella Stephens, 1835, Amaurodera Fauvel, 1905, Tetrabothrus Bernhauer, 1915 und Lomechusoides Tottenham, 1939 werden aus der Paläarktis gemeldet, darunter der Erstnachweis von Pella lugens (Gravenhorst, 1802) aus der Ostpaläarktis. Der bisher unbekannte Aedoeagus von Pella reuteri Assing, 2008, die zuvor unbekannten weiblichen Geschlechtsmerkmale von Amaurodera ilamica Assing, 2005 sowie die primären Sexualmerkmale einiger aus China nachgewiesener Pella-Arten werden abgebildet. Die Verbreitung der derzeit aus China bekannten Drusilla-Arten wird anhand von Karten illustriert. 


\section{Introduction}

The speciose polyphyletic tribe Lomechusini has attracted the attention of entomologists more than other tribes of the Aleocharinae, primarily because many of its species are myrmecophilous or termitophilous. In a recent catalogue HLAváč et al. (2011) listed 2205 species and subspecies worldwide. Additional species have been described in the meantime. According to ScHüLKE \& Smetana (in press), the Lomechusini is represented in the Palaearctic region sensu Smetana (2004) by three subtribes with 28 genera and 357 species and subspecies, the Lomechusina (two genera, 37 species), the Myrmedoniina (22 genera, 316 species), the Termitozyrina (three genera, three species), plus one genus and species incertae sedis. The most speciose genera are Zyras Stephens, 1835 (98 species recorded from the Palaearctic), Drusilla LeACH, 1819 (58), and Pella Stephens, 1835 (51), followed by Orphnebius Motschulsky, 1858 (32), Amaurodera FAuvel, 1905 (20), Lomechusa Gravenhorst, 1806 (19), Lomechusoides Tottenham, 1939 (18), and Myrmoecia Mulsant \& Rey, 1873 (17).

Material examined since the latest contribution to the Lomechusini of the Palaearctic region (Assing 2010) included several new species and records of zoogeographic interest. The genus Orphnebius and the Chinese species of Tetrabothrus BERNHAUER, 1915 were treated separately (Assing 2015a, b). The present paper deals with species of Drusilla, Pella, Amaurodera, Tetrabothrus, and Lomechusoides, primarily from China.

\section{Material and methods}

The material treated in this study is deposited in the following collections:

MHNG Muséum d'Histoire Naturelle, Genève (G. Cuccodoro)

MNHUB Museum für Naturkunde der HumboldtUniversität Berlin (J. Frisch, J. Willers)

NHMB Naturhistorisches Museum Basel (I. Zürcher)

NME Naturkundemuseum Erfurt (M. Hartmann)

NMP National Museum of Natural History, Praha (J. Hájek)

cApf private collection Wolfgang Apfel, Eisenach

cAss author's private collection

cFel private collection Benedikt Feldmann, Münster

cGon private collection Andrej Gontarenko, Odessa

cKoc private collection Matúš Kocian, Praha

cPüt private collection Andreas Pütz, Eisenhüttenstadt

cSch private collection Michael Schülke, Berlin

cSha private collection Alexey Shavrin, Daugavpils

cSme private collection Aleš Smetana, Ottawa
The morphological studies were conducted using a Stemi SV 11 microscope (Zeiss Germany) and a Jenalab compound microscope (Carl Zeiss Jena). The images of the external characters were created using a photographing device constructed by Arved Lompe (Nienburg) and CombineZ software. A digital camera (Nikon Coolpix 995) was used for the remaining photographs. The maps were created using MapCreator 2.0 (primap) software.

Body length was measured from the anterior margin of the labrum to the apex of the abdomen, the length of the forebody from the anterior margin of the labrum to the posterior margin of the elytra, head length from the anterior margin of the clypeus (without ante-clypeus) to the posterior constriction of the head, the length of the elytra along the suture from the apex of the scutellum to the posterior margin of the elytra, the length of the median lobe of the aedeagus from the apex of the ventral process to the base of the aedeagal capsule, and the length of the spermatheca is given as the maximal extension (measured from the apex of the distal portion of the capsule). The "parameral" side of the median lobe of the aedeagus (i.e., the side where the sperm duct enters) is referred to as the ventral, the opposite side as the dorsal aspect.

\section{Descriptions and additional records}

\subsection{Drusilla LEACH, 1819}

\section{Drusilla canaliculata (FABRICIUS, 1787)}

Drusilla puncticollis Moтschulsky, 1845: 360; syn. nov.

Material examined: Turkey: $1 \sigma^{\star}$, Nevşehir, Göre, 21.IV.1992, leg. Kocian (cKoc). Iran: 1 우, Ardabil province, $20 \mathrm{~km}$ NE Khalkhal, $37^{\circ} 41^{\prime} \mathrm{N}, 48^{\circ} 23^{\prime} \mathrm{E}, 1480 \mathrm{~m}$, 13.X.2011, leg. Frisch (MNHUB); 1 ㅇ, Gilan province, Bandar-e Anzali, Bashm, 37 $30^{\prime} \mathrm{N}, 4^{\circ} 21^{\prime} \mathrm{E}, 0 \mathrm{~m}$, marshland, 1.V.2012, leg. Weipert (NME).

Kyrgyzstan: 1 우, Issyk-Kul, Tyup, $42^{\circ} 45^{\prime} \mathrm{N}, 78^{\circ} 23^{\prime} \mathrm{E}$, 1620 m, 28.VI.2011, leg. Frisch (MNHUB); 1 옹 IssykKul, Balykchy - Cholpon-Ata, Semenovka, $42^{\circ} 46^{\prime} \mathrm{N}$, 77³2'E, 1860 m, 30.VI.2011, leg. Frisch (cAss).

Japan: 1 ex., Hokkaido, Sapporo env., Nopporo virgin forest, 15.V.2010, leg. Lackner (cAss); 2 exs., Hokkaido, Sapporo, Hokudai Campus, VII.2011, leg. Lackner (cAss).

Comment: Drusilla puncticollis, whose descriptions is based on two syntypes from "Kamtschatka" (Motschulsky 1845), was previously treated as a subspecies of D. canaliculata (SMEtana 2004). According to Motschulsky (1845), who already expressed doubts regarding the status of this taxon ("Je propose cette espèce avec doute"), D. puncticollis is distinguished from $D$. canaliculata by larger body size, darker coloration, and a more deeply impressed pronotum. Examined material from the eastern East Palaearctic region indeed 
tends to be darker and of slightly larger size than material from West Europe; for previous records see Assing (2005a, b, 2006b, 2008a, 2009, 2010). However, similar character conditions have been observed also in specimens from some regions in Middle Asia and the West Palaearctic region (particularly Iran), suggesting that these differences should be interpreted as intraspecific, possibly clinal variation. Moreover, the presence of a distinct subspecies in Kamchatka appears most unlikely. Hence the synonymy proposed above.

The previously known trans-Palaearctic distribution of D. canaliculata extended from West Europe to the Russian Far East (Smetana 2004). The above specimens from Hokkaido represent the first records from Japan.

\section{Drusilla memnonia (MÄRKEL, 1844)}

Material examined: Tunisia: 3 exs., Béja, Djebba, $36^{\circ} 28^{\prime} \mathrm{N}$, $9^{\circ} 05^{\prime} \mathrm{E}, 640 \mathrm{~m}$, 3.III.2012, leg. Th. Schmidt (cAss); 15 exs., Béja, $11 \mathrm{~km}$ W Teboursouk pass, $36^{\circ} 30^{\prime} \mathrm{N}, 9^{\circ} 10^{\prime} \mathrm{E}, 700 \mathrm{~m}$, under stones, 1.III.2012, leg. Meybohm (cAss); 10 exs. same data, but leg. Hetzel (cFel); 2 exs., Béja, Djebba, $36^{\circ} 28^{\prime} \mathrm{N}, 9^{\circ} 06^{\prime} \mathrm{E}, 630 \mathrm{~m}$, near rocks, sifted, 4.III.2012, leg. Meybohm (cAss); 7 exs., Béja, Djebba, $36^{\circ} 28^{\prime} \mathrm{N}, 9^{\circ} 05^{\prime} \mathrm{E}$, $640 \mathrm{~m}$, moist arable land, 4.III.2012, leg. Meybohm (cAss); 15 exs., same data, but leg. Hetzel (cFel).

Comment: This species is distributed in North Africa and Sicily (Assing 2005b, 2005c, 2006b, 2010).

\section{Drusilla kabyliana FAGEL, 1958}

Material examined: Tunisia: 1 ex., Jendouba, 8 km S Aïn Draham, $36^{\circ} 43^{\prime} \mathrm{N}, 8^{\circ} 42^{\prime} \mathrm{E}, 610 \mathrm{~m}$, oak forest, 2.III.2012, leg. Meybohm (cAss); 1 ex., same data, but leg. Hetzel (cFel); 14 exs., Jendouba, National Park El Feija, $36^{\circ} 28^{\prime} \mathrm{N}$, $8^{\circ} 14^{\prime} \mathrm{E}, 590 \mathrm{~m}$, arable land, 3.III.2012, leg. Meybohm (cAss); 9 exs., same data, but leg. Hetzel (cFel); 2 exs., same data, but $36^{\circ} 29^{\prime} \mathrm{N}, 8^{\circ} 20^{\prime} \mathrm{E}, 520 \mathrm{~m}$, clearing in oak forest, under stones, leg. Hetzel (cFel).

Comment: The distribution of D. kabyliana is confined to Algeria and Tunisia (Assing 2005c, 2008a).

\section{Drusilla foreli (WASMANn, 1890)}

Material examined: Tunisia: 23 exs., Béja, $11 \mathrm{~km} \mathrm{~W}$ Teboursouk pass, $36^{\circ} 30^{\prime} \mathrm{N}, 9^{\circ} 10^{\prime} \mathrm{E}, 700 \mathrm{~m}, 1 . I I I .2012$, leg. Meybohm (cAss); 3 exs., Béja, W Djebba, Teboursuk, $36^{\circ} 28^{\prime} \mathrm{N}, 9^{\circ} 05^{\prime} \mathrm{E}, 640 \mathrm{~m}$, wet fields, under stones, 4.III.2012, leg. Aßmann (cFel).

Comment: This anophthalmous representative of the subgenus Apteranopsis JeAnNEL, 1960 is locally endemic in Tunisia (Assing 2005b).

\section{Drusilla meridiana (FAUVEL, 1900)}

Material examined: Greece, Pelopónnisos: $10^{\star}, 1$, Ahaia, Oros Aroania, 1550 m, 4.VI.2007, leg. Giachino \& Vailati (cAss); 1 ex., NW Panapoulos, $37^{\circ} 50^{\prime} \mathrm{N}, 21^{\circ} 40^{\prime} \mathrm{E}$, 540 m, oak forest, 3.V.2007, leg. Schnitter \& Arndt (cApf); 1 ex., Korinthia, Feneós, oak forest, pitfall, 28.VII.2005, leg. Arndt (cApf).

Comment: Drusilla meridiana is endemic to the Pelopónnisos, southern Greece (Assing 2005b, 2010).

\section{Drusilla italica (BernhaUER, 1903)}

Material examined: Italy: 1 ex., Salerno, Montecorvino Rovella, M. Corvino, garden, 27.VI.2009, leg. Frenzel (cApf).

Comment: The distribution of D. italica is confined to Italy, where it is widespread and rather common. For a distribution map see Assing (2006b).

\section{Drusilla besucheti Assing, 2005}

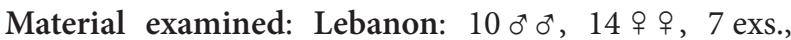
Rayfoun, $33^{\circ} 58^{\prime} \mathrm{N}, 35^{\circ} 42^{\prime} \mathrm{E}, 990 \mathrm{~m}$, mixed oak forest, 15.III.2013, leg. Reuter (cAss, cFel); 2 exs., same data, but pitfall trap, 18.XI.2012 (cFel); 11 exs., same data, but pitfall trap, 30.III-5.IV.2013 (cFel); 1 ex., 27 km NE Beirut, Kafr Debian env., 1200 m, oak forest, pitfall trap, 9.XI.2012, leg. Reuter (cFel).

Comment: This species has been recorded only from Lebanon (Assing 2005b)

\section{Drusilla denigrata Assing, 2005}

Material examined: Turkey: 12 exs., Hatay, 15 km WSW Antakya, Batiayaz, Musa Dağ, ca. 500 m, pitfall trap, 6.-23.IV.2014, leg. Reuter (cFel).

Comment: The known distribution of $D$. denigrata is confined to the Turkish province Hatay and northern Syria (Assing 2005b, 2010).

\section{Drusilla heydeni (EPPELSHEIM, 1887)}

Material examined: Kyrgyzstan: $2 \sigma^{\top} \sigma^{\star}$, Issyk-Kul, Kek Mojnok-Vtoroe - Balykchy, 42²7'N, 7551'E, $1580 \mathrm{~m}$, 19.VI.2011, leg. Frisch (MNHUB, cAss); $10^{\star}$, Issyk-Kul, Tyup, Ak Bulak, 42 $49^{\prime} \mathrm{N}, 78^{\circ} 14^{\prime} \mathrm{E}, 1910$ m, 29.VI.2011, leg. Frisch (MNHUB); $10^{\star}$, Chui, SE Bishkek, $11 \mathrm{~km}$ W Yurevka, 42 $44^{\prime} \mathrm{N}, 74^{\circ} 55^{\prime} \mathrm{E}, 1100 \mathrm{~m}$, 4.VII.2011, leg. Frisch (MNHUB); $10^{\star}$, Chui, SW Tokmok, Kegety, 
$42^{\circ} 37^{\prime} \mathrm{N}, 75^{\circ} 08^{\prime} \mathrm{E}, 1500 \mathrm{~m}, 3 . \mathrm{VII} .2011$, leg. Frisch (cAss); $10^{*}, 1$ ex., Chui, S Bishkek, SW Koytash, Tatyr, $42^{\circ} 40^{\prime} \mathrm{N}$, 74³9'E, 1500 m, 5.VII.2011, leg. Frisch (MNHUB, cAss); 2 exs., Batken, Isfana-Isfara, WSW Ozgorush, tributary of Lyailek river, $39^{\circ} 44^{\prime} \mathrm{N}, 70^{\circ} 00^{\prime} \mathrm{E}, 1560 \mathrm{~m}, 23 . \mathrm{VI} .2012$, leg. Frisch (MNHUB, cAss); 30 exs., Batken, S Quvasoy, Majdan, $40^{\circ} 05^{\prime} \mathrm{N}, 72^{\circ} 04^{\prime} \mathrm{E}, 1370 \mathrm{~m}, 17 . \mathrm{VI} .2012$, leg. Frisch (MNHUB); 1 ex., Batken, S Quvasoy, S Karaul, Austan, $39^{\circ} 58^{\prime} \mathrm{N}, 7^{\circ} 07^{\prime} \mathrm{E}, 1380 \mathrm{~m}, 18 . \mathrm{VI} .2012$, leg. Frisch (MNHUB); 1 ex., Batken, S Quvasoy, 2 km N Langar, $\quad 39^{\circ} 52^{\prime} \mathrm{N}, \quad 72^{\circ} 05^{\prime} \mathrm{E}, 1610 \mathrm{~m}, \quad 18 . \mathrm{VI} .2012$ (MNHUB); 20 exs., Batken, SW Isfana, Dinau, 39 $42^{\prime} \mathrm{N}$, $69^{\circ} 22^{\prime} \mathrm{N}, 1770 \mathrm{~m}, 24 . \mathrm{VI} .2012$, leg. Frisch (MNHUB, cAss); 1 ex., Batken, Isfana-Isfara, WSW Ozgorush, Lyailek river, $39^{\circ} 44^{\prime} \mathrm{N}, 70^{\circ} 00^{\prime} \mathrm{E}, 1520 \mathrm{~m}, 22 . \mathrm{VI} .2012$, leg. Frisch (cAss); 6 exs., Batken, Isfana-Isfara, WSW Ozgorush, tributary of Lyailek river, $39^{\circ} 44^{\prime} \mathrm{N}, 70^{\circ} 00^{\prime} \mathrm{E}$, $1560 \mathrm{~m}, 23 . \mathrm{VI} .2012$, leg. Frisch (MNHUB, cAss); 1 ex., Batken, E Sovetsky, 400 $7^{\prime} \mathrm{N}, 71^{\circ} 23^{\prime} \mathrm{E}, 1410 \mathrm{~m}$, 20.VI.2012, leg. Frisch (MNHUB); 2 exs., Batken, ESE Sovetsky, $40^{\circ} 5^{\prime} \mathrm{N}, 71^{\circ} 23^{\prime} \mathrm{E}, 1790 \mathrm{~m}, 20 . \mathrm{VI} .2012$, leg. Frisch (MNHUB, cAss); 7 exs., Jalal Abad, ESE Toktogul, Torkent, $41^{\circ} 51^{\prime} \mathrm{N}, 73^{\circ} 10^{\prime} \mathrm{E}, 960 \mathrm{~m}, 2$.VII.2012, leg. Frisch (MNHUB, cAss); 5 exs., Jalal Abad, NE Karakul, N Kekbel, Kekbel pass, $41^{\circ} 43^{\prime}$ N, $72^{\circ} 55^{\prime}$ E, 1420 m, 2.VII.2012, leg. Frisch (MNHUB, cAss).

Tajikistan: $1 \sigma^{\top}$, Varzob district, $48 \mathrm{~km}$ N Dushanbe, Khodja Obi Gharm, 1900 m, 3.-4.VII.2012, leg. Valainis (cSha).

Comment: Drusilla heydeni is widespread in Middle Asia, where it is the most common representative of the genus (Assing 2005a, 2008a, 2011).

\section{On the Drusilla fauna of China}

Twelve species of Drusilla had been recorded from China (exclusive of Taiwan and Hong Kong): Drusilla aino NAKANE, 1963 (Japan; doubtfully recorded from Jilin), D. cenwanglaomontis PACE, 2012 (Guangxi); D. damingensis PACE, 2012 (Guangxi), D. dendrolasii Maruyama \& Kishimoto, 2002 (Hunan), D. gibberella PACE, 1998 (China: Hainan; Hong Kong; Nepal), D. gilva PaCe, 2012 (Sichuan), D. imurai Maruyama \& Kishimoto, 2002 (Hubei), D. philippina (Bernhauer, 1915) (Hainan), D. sinicola PACE, 2012 (Sichuan), D. watanabei Maruyama \& Kishimoto, 2002 (Hubei, Hunan), D. yunnanensis PACE, 1993 (Hubei, Hunan, Yunnan), and D. zhejiangensis PACE, 1998 (Zhejiang) (Maruyama \& Kishimoto 2002a, b; Pace 1993, 1998, 2006, 2012).

Unlike most Drusilla species from the West Palaearctic region, at least some of the species recorded from China are remarkably widespread. This even applies to the micropterous D. watanabei. The distributions of the Chinese representatives of the genus are illustrated in Maps 1-2.

The examined recently collected Drusilla material from the Chinese province Yunnan is composed of four species, two of them described previously and two undescribed. In order to facilitate future identification of D. watanabei and D. yunnanensis, both species are redescribed and newly illustrated. The two new species are distinguished from the three Drusilla species recorded from Burma (D. assamensis (Cameron, 1939), D. feae (Cameron, 1939), D. malaisei (SCheERPeltz, 1965)) by different coloration alone.

\section{Drusilla gilva PACE, 2012}

Type material examined: Holotype $9:$ "China: Sichuan, Qingcheng Shan, 65 km NW Chengdu, 103.33E, 30.53N, 18.V./3.-4.VI.1997, $800 \mathrm{~km} \mathrm{~W} \mathrm{Taiping,} \mathrm{800-1000} \mathrm{m,}$ leg. A. Pütz / Holotypus Drusilla gilva mihi, det. R. Pace 2009 / Drusilla gilva n. sp., det. R. Pace 2009” (cPüt).

Comment: The original description is based on one female specimen from "Sichuan, Qingcheng Shan, 65 km NW Chengdu” (PACE 2012).

\section{Drusilla (Drusilla) watanabei Maruyama \& Kishimoto, 2002 \\ (Figs 1-13)}

Material examined: China: Yunnan: $3 o^{\star} o^{\star}, 1$ 우, mountains W Dongchuan, Sedan Snow Mountain Scenic Resort, $26^{\circ} 06^{\prime} \mathrm{N}, 102^{\circ} 55^{\prime} \mathrm{E}, 2620 \mathrm{~m}$, secondary pine forest, litter, moss, and roots of herbs sifted, 14.VIII.2014, leg. Assing (cAss).

Comment: The original description is based on 16 type specimens from two localities in Hubei and Hunan provinces (Maruyama \& Kishimoto 2002a). The authors did not find (and illustrate) a spermatheca, although the type series includes seven females. A full redescription is provided below.

Description: Relatively large species; body length 7.0-7.8 mm; length of forebody $2.6-3.0 \mathrm{~mm}$. Coloration: body black, with the posterior margins of the abdominal segments paler; legs with the tibiae and tarsi yellowish to dark-yellowish, the profemora blackish, the mesofemora blackish with the basal third yellowish, and the metafemora yellowish in basal half and infuscate in apical half; antennae reddish-yellow, with antennomere I weakly to distinctly infuscate; maxillary palpi dark-brown, with the terminal palpomere reddish-yellow.

Head (Figs 1-2) with sexually dimorphic punctation and with fine and shallow microreticulation. Eyes distinctly shorter than distance from posterior margin of eye to posterior constriction of head. Antenna (Fig. 3) 2.6-2.9 mm long and slender; all antennomeres at least weakly oblong. Pronotum (Figs 1-2) 1.00-1.05 times as long as broad and 1.17-1.18 times as broad as head, broadest in anterior half; posterior angles weakly marked; near posterior margin with pronounced transverse impression; other 


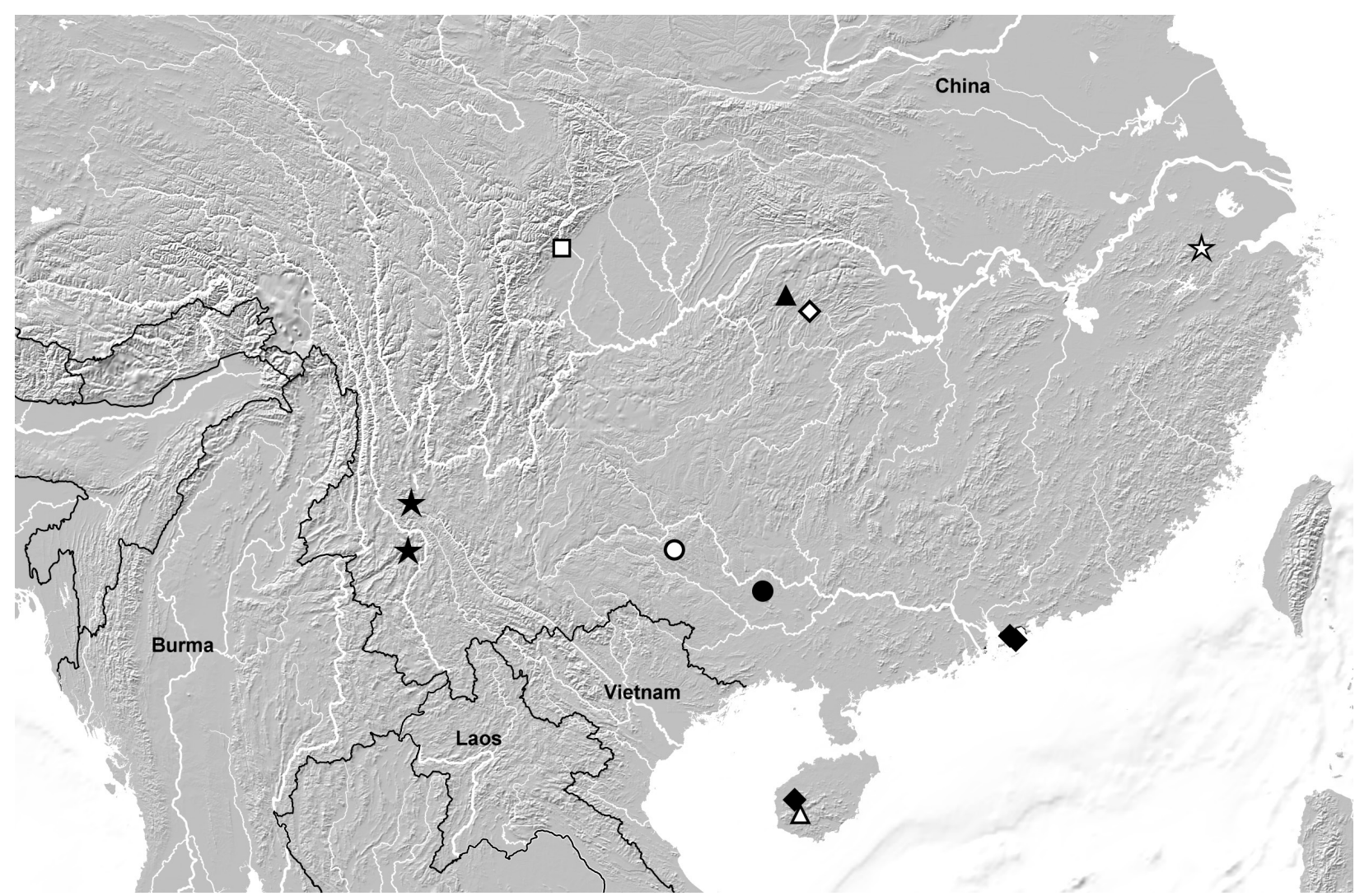

Map 1: Distributions of Drusilla species recorded from China: D. flagellata (black stars); D. gilva (white square); D. imurai (black triangle); D. dendrolasii (white diamond); D. zhejiangensis (white star); D. cenwanglaomontis (white circle); D. damingensis (black circle); D. gibberella (black diamonds); D. philippina (white triangle).

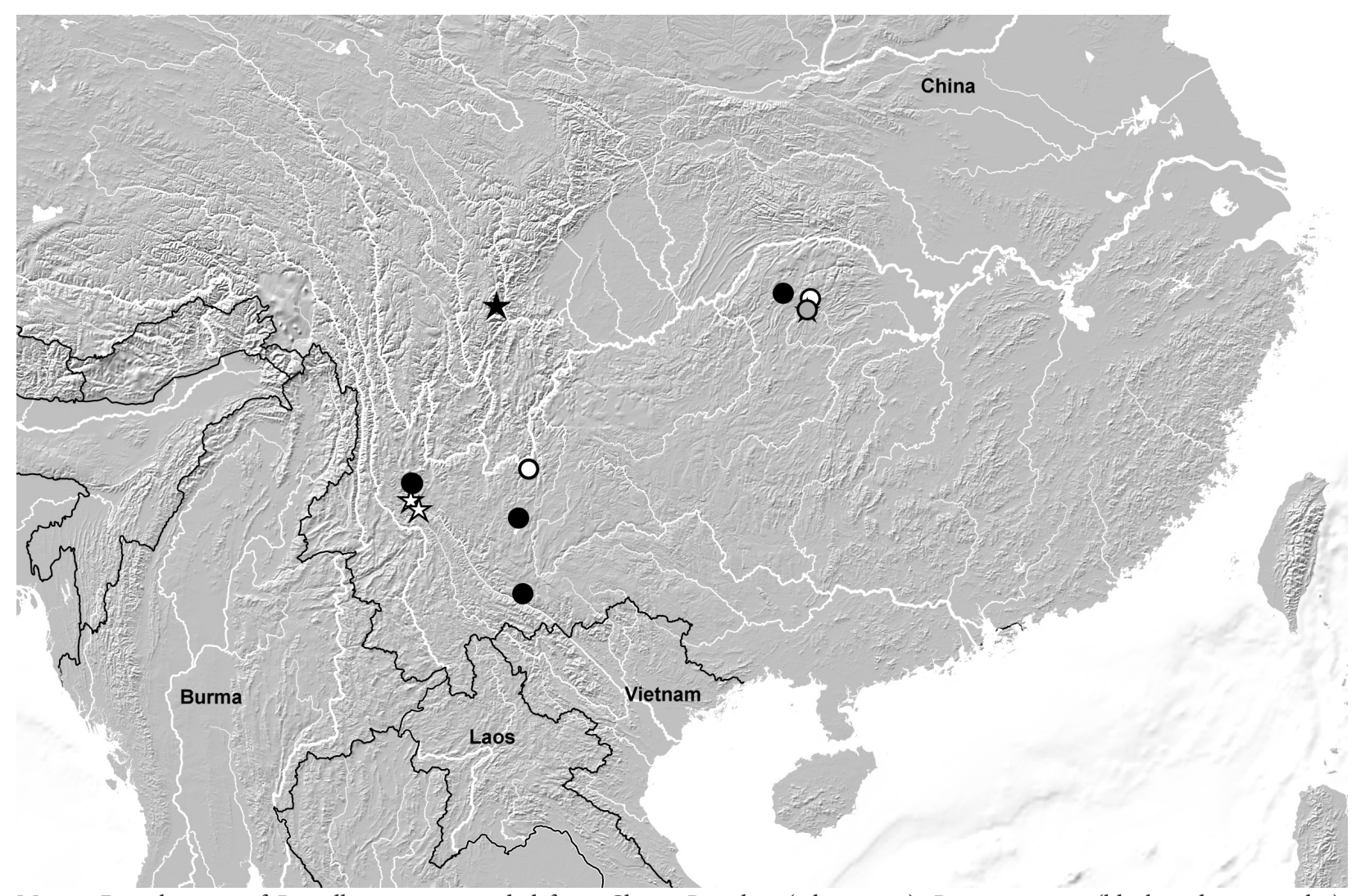

Map 2: Distributions of Drusilla species recorded from China: D. palata (white stars); D. yunnanensis (black and grey circles); D. watanabei (white and grey circles); D. sinicola (black star). 
impressions and punctation sexually dimorphic; interstices without microsculpture and glossy.

Elytra (Figs 1-2) short, approximately 0.65 times as long as pronotum; humeral angles moderately marked; punctation sexually dimorphic; interstices without microsculpture. Hind wings reduced to short stubs extending slightly beyond posterior margin of elytra. Metatarsomere I elongate, approximately as long as the combined length of II-IV.

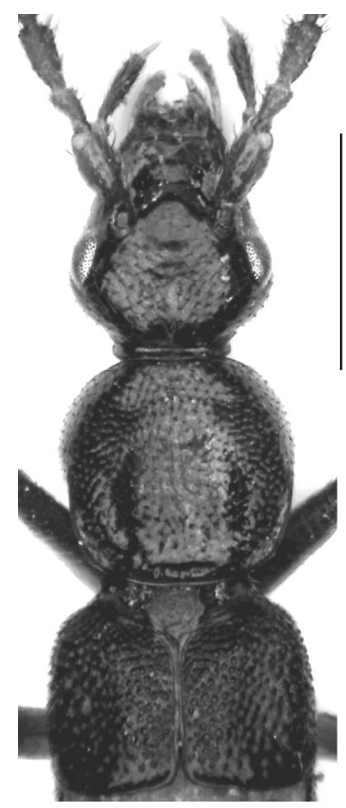

1

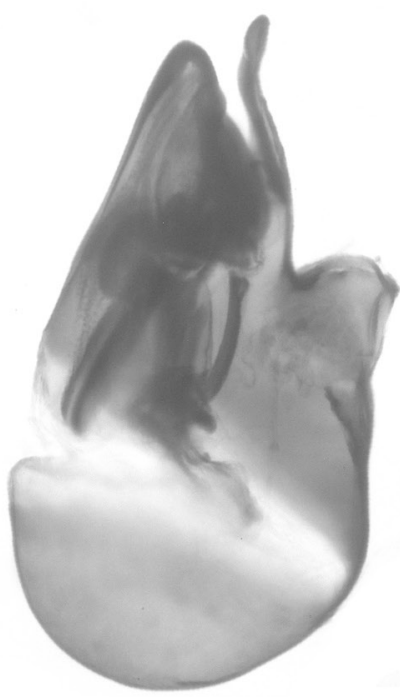

7

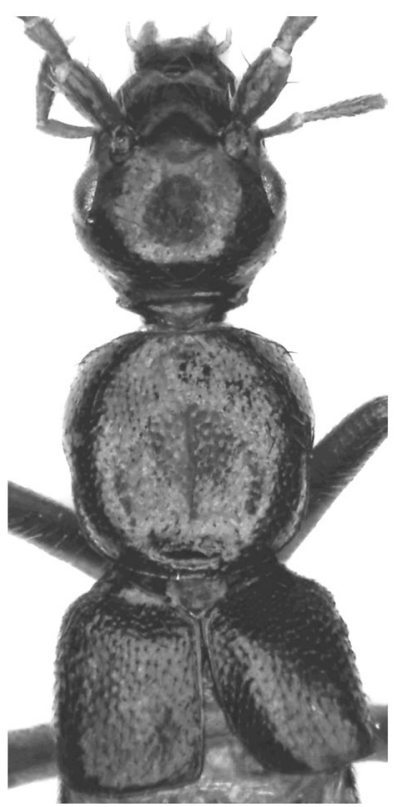

2

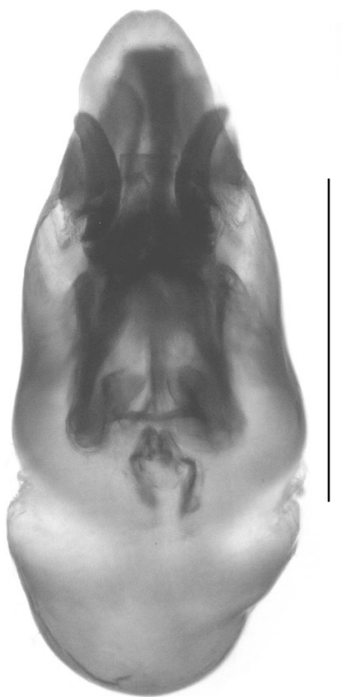

8

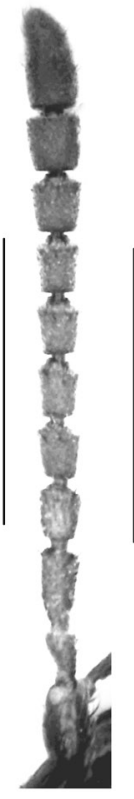

3

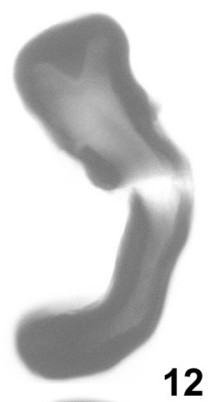

12

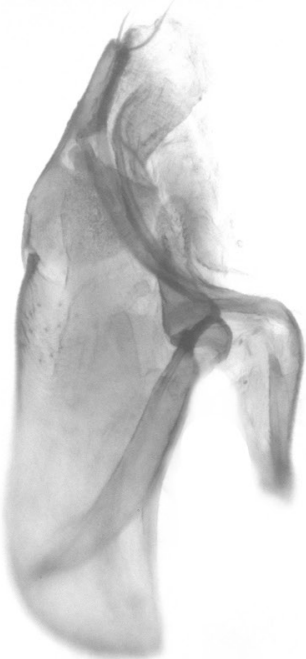

9

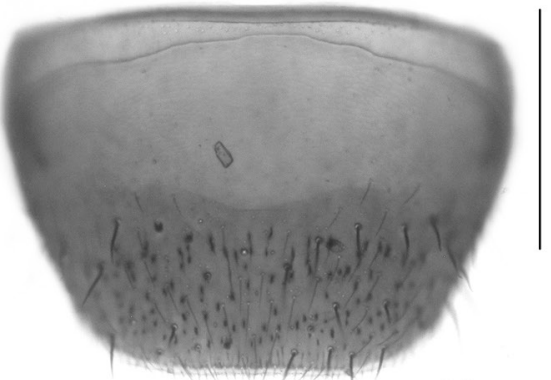

11

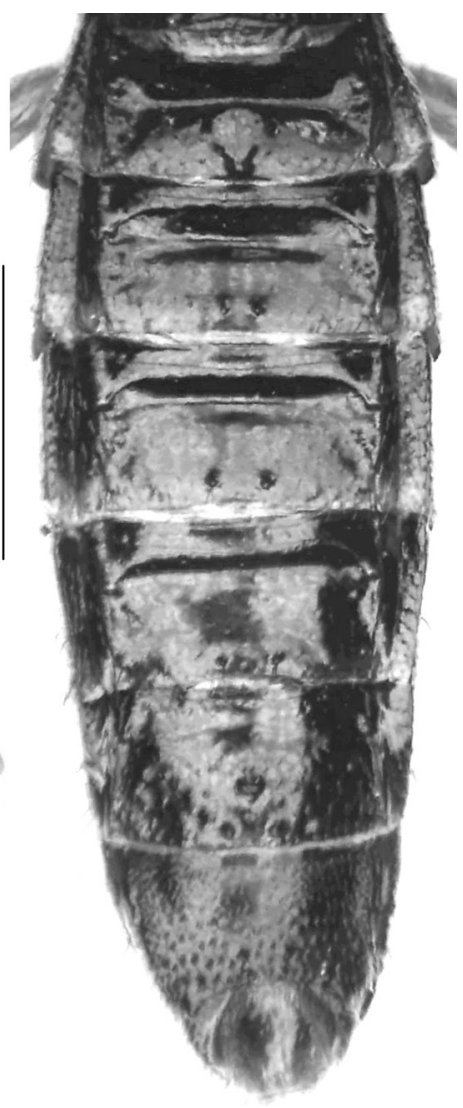

4

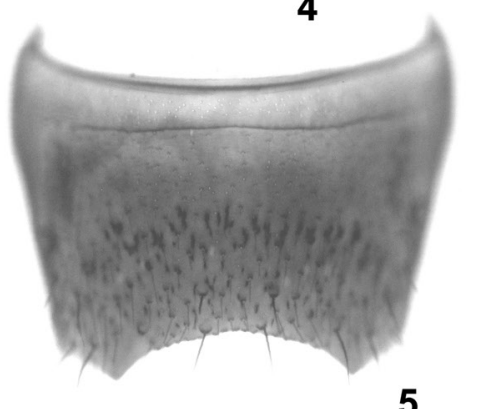

5

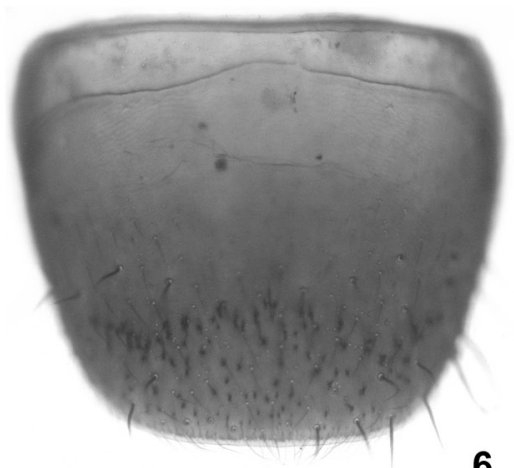
6

10

Figs 1-13: Drusilla watanabei: male forebody (1); female forebody (2); antenna (3); male abdomen (4); male tergite VIII (5); male sternite VIII (6); median lobe of aedeagus in lateral and in ventral view (7-8); paramere (9); female tergite VIII (10); female sternite VIII (11); spermatheca in different aspects (12-13). Scale bars: 1-4: $1.0 \mathrm{~mm}$; 5-11: $0.5 \mathrm{~mm}$; 12-13: $0.2 \mathrm{~mm}$. 
Abdomen (Fig. 4) distinctly broader than elytra; tergites III-VIII with sexual dimorphism; punctation sexually dimorphic; anterior impressions of tergites IIIVI impunctate; tergites with very weak, nearly obsolete transverse microsculpture; posterior margin of tergite VII with palisade fringe.

$0^{\text {* }}$ : lateral portions of dorsal surface of head with dense and rather coarse punctation, with the interstices narrower than diameter of punctures; frons, posterior portion, and the narrow midline of the head impunctate or nearly so (Fig. 1); pronotum in posterior half with pronounced longitudinal elevation on either side, between these elevations with broadly flattened impression; median portion of pronotum somewhat shiny and with moderately dense and moderately coarse punctation, with the interstices as broad as, or broader than, diameter of punctures; lateral portions of pronotum practically matt, with very dense and coarsely granulose punctation, with the interstices narrower than diameter of punctures (Fig. 1); elytra with dense and coarsely granulose punctation (Fig. 1); abdominal tergite III (Fig. 4) with a pronounced median tubercle of somewhat variable shape and with scattered fine punctures; tergites IV-VI each with a median pair of distinct granules near posterior margin, impunctate (or nearly so), except for some punctures at posterior margins; tergite VII with a pronounced median granule and numerous additional smaller granules in posterior half (Fig. 4); tergite VIII (Fig. 5) with densely granulose punctation and with distinct microreticulation, posterior margin broadly concavely excavate; sternite VIII (Fig. 6) weakly transverse and with nearly truncate posterior margin; median lobe of aedeagus large, 1.0-1.1 mm long, shaped as in Figs 7-8; paramere $0.9 \mathrm{~mm}$ long and shaped as in Fig. 9.

ㅇ: head (Fig. 2) with sparse and very fine punctation, interstices much broader than diameter of punctures; pronotum (Fig. 2) with weakly pronounced elevations in posterior half; punctation moderately fine, moderately dense, and non-granulose; elytra (Fig. 2) with weakly granulose puncation; abdominal tergites III-V with fine and sparse punctation; tergite VI impunctate except for a median pair of setiferous punctures bearing long dark setae and additional punctures at posterior margin; tergite VII with a median pair of setiferous punctures bearing long dark setae and with additional fine and sparse punctation in posterior half; posterior margin of tergite VIII somewhat truncate, only indistinctly concave in the middle (Fig. 10); sternite VIII (Fig. 11) distinctly shorter and more transverse than that of male, posterior margin truncate; spermatheca very small in relation to body size, $0.25 \mathrm{~mm}$ long, and shaped as in Figs 12-13.

Comparative notes: This highly distinctive species differs from other Drusilla species known from China by numerous characters, particularly its large body size, the long and slender antennae, the short elytra, the reduced hind wings, the male secondary sexual characters, and the male and female primary sexual characters.
Distribution and natural history: The known distribution now includes a total of three localities in Hubei, Hunan, and Yunnan provinces. The examined specimens were sifted from litter, moss, and the roots of herbs in a terraced secondary pine forest at an altitude of $2620 \mathrm{~m}$. Maruyama \& Kishimoto (2002a) found D. watanabei associated with the ant Lasius (Dendrolasius) spathepus WHEELER, 1910.

\section{Drusilla (Drusilla) flagellata spec. nov.} (Figs 14-25)

Type material: Holotype ơ: “CHINA (Yunnan) Dali Bai Aut. Pref., Wuliang Shan, 20 km NW Weishan 1900 m (creek valley, under bank vegetation, stones, gravel) 2519'58"N, 10007'59"E, 17.IX.2009 D.W. Wrase [58] / Holotypus ơ Drusilla flagellata spec. nov. det. V. Assing 2015" (cAss).

Paratypes: $4 \sigma^{\star} \sigma^{\star}, 2$ ㅇ + : same data as holotype (cSch, cAss); $10^{\star}, 1$ ㅇ: same data, but leg. Schülke (cSch); $10^{*}$ : "CHINA (Yunnan) Lincang Pref., Xue Shan, $48 \mathrm{~km} \mathrm{~N}$ Lincang $2070 \mathrm{~m}, 24^{\circ} 19^{\prime} 03^{\prime \prime} \mathrm{N}, 100^{\circ} 07^{\prime} 13^{\prime \prime} \mathrm{E}$ (slope close to small pond, in loamy soil, plant roots) 12.IX.2009, D.W. Wrase [45]" (cAss).

Etymology: The specific epithet (Latin, adjective) alludes to the conspicuously long flagellum in the internal sac of the aedeagus.

Description: Body size variable; body length 4.5-6.5 mm; length of forebody $2.2-2.7 \mathrm{~mm}$. Coloration: head, pronotum, and abdomen blackish; elytra dark-yellowish, with the scutellar region and the postero-lateral angles extensively infuscate; legs pale-yellowish, with the apices of the femora more or less distinctly infuscate; antennae black; maxillary palpi reddish to reddish-brown, with the terminal palpomere yellow.

Head (Figs 14-15) approximately 1.2 times as broad as long; dorsal surface with scattered and very fine punctation, without microsculpture, and glossy. Eyes large and bulging, much longer than distance from posterior margin of eye to posterior constriction of head. Antenna (Fig. 16) 2.0-2.3 mm long; antennomeres III-X gradually increasing in width; antennomere $\mathrm{X}$ approximately as long as broad.

Pronotum (Figs 14-15) 1.02-1.06 times as broad as long and 1.06-1.09 times as broad as head, broadest at anterior angles; posterior angles obtusely marked; posteriorly with small impression of more or less triangular shape; midline with narrow, deep, and sharply delimited furrow extending from posterior impression cephalad, but not reaching anterior margin of pronotum; punctation dense and distinct, not granulose, subject to weakly pronounced sexual dimorphism; interstices without microsculpture and glossy.

Elytra (Figs 14-15) approximately 0.9 times as long as pronotum; humeral angles marked; punctation dense, 
similar to that of pronotum. Hind wings fully developed. Metatarsomere I nearly as long as the combined length of II-IV.

Abdomen (Fig. 17) narrower than elytra; tergites IIIVII without sexual dimorphism; anterior impressions of tergites III-V and posterior margins of tergites III-VI with fine punctation, remainder of tergal surfaces with scattered and conspicuously sparse punctation, nearly impunctate; posterior margin of tergite VII with palisade fringe.

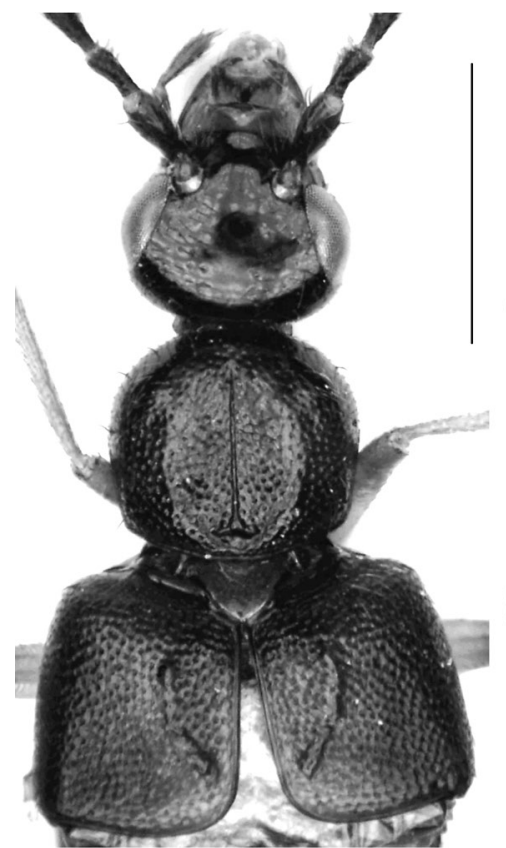

14

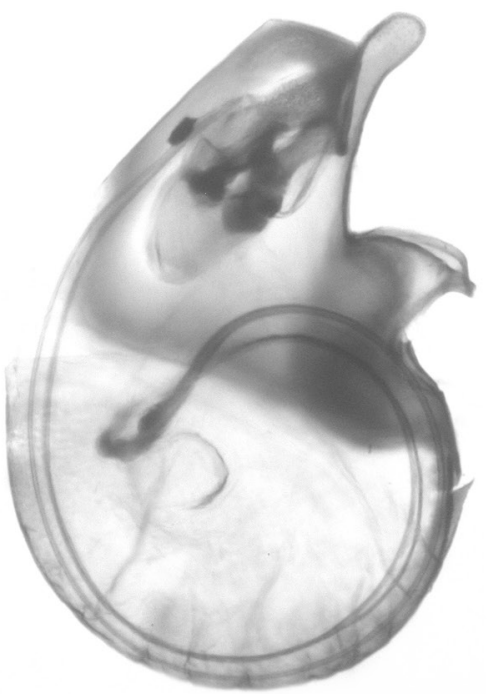

20

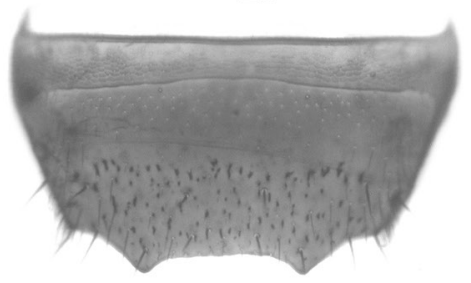

23

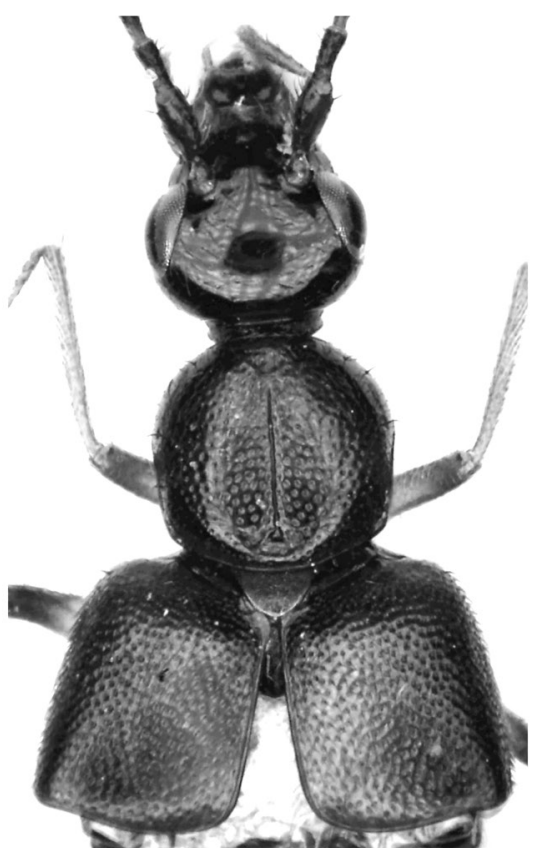

15

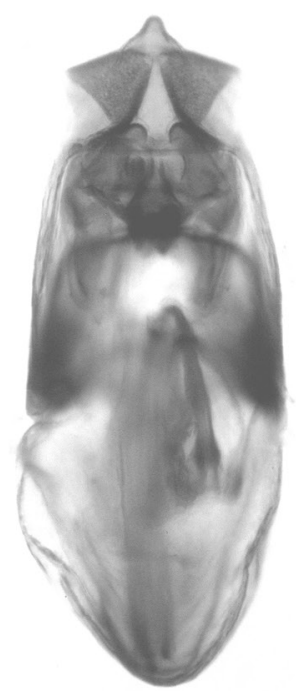

21

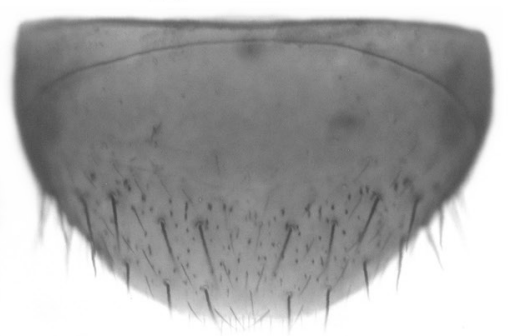

24

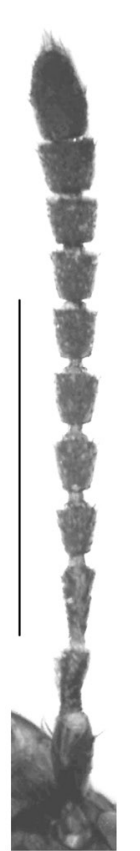

16

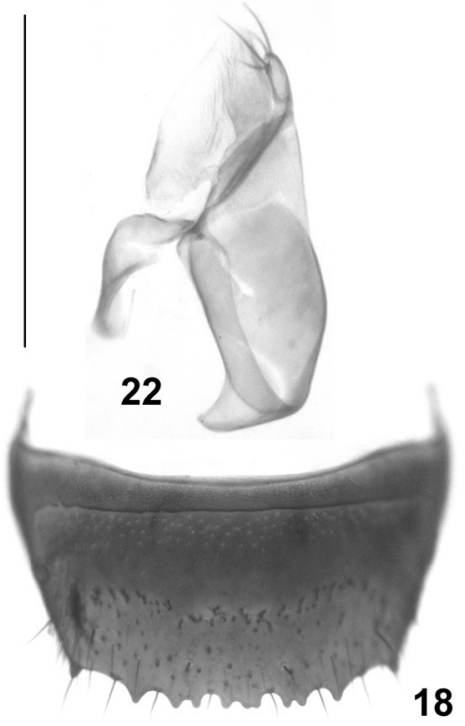

18

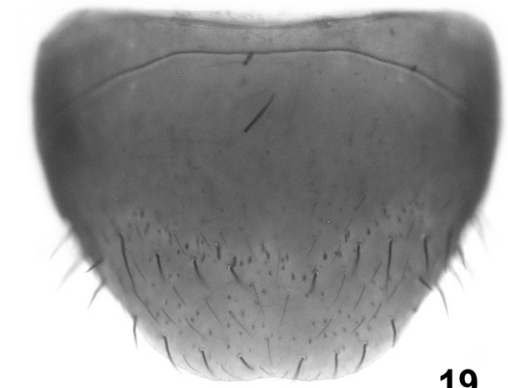

19

Figs 14-25: Drusilla flagellata spec. nov.: male forebody (14); female forebody (15); antenna (16); male abdomen (17); male tergite VIII (18); male sternite VIII (19); median lobe of aedeagus in lateral and in ventral view (20-21); paramere (22); female tergite VIII (23); female sternite VIII (24); spermatheca (25). Scale bars: 14-17: $1.0 \mathrm{~mm}$; 18-24: $0.5 \mathrm{~mm}$; 25: $0.2 \mathrm{~mm}$. 
$\sigma^{7}$ : pronotum (Fig. 14) with extensive, but not very deep median impression with somewhat denser punctation; elytra in large males each with conspicuous oblong and oblique elevation (Fig. 14); tergite VIII (Fig. 18) strongly transverse and with distinctly serrate posterior margin; sternite VIII (Fig. 19) transverse, posterior margin truncate in the middle; median lobe of aedeagus (Figs 20-21) $1.0 \mathrm{~mm}$ long and of highly distinctive morphology, laterally somewhat flattened, with short ventral process, and with long flagellum in internal sac; paramere (Fig. 22) very small, approximately $0.55 \mathrm{~mm}$ long, little more than half as long as median lobe.

ㅇ: pronotum (Fig. 15) flattened, but not impressed in the middle; tergite VIII (Fig. 23) strongly transverse, posterior margin with a triangular projection on either side; sternite VIII (Fig. 24) distinctly shorter and more transverse than that of male, posterior margin convex; spermatheca long and of distinctive shape (Fig. 25).

Intraspecific variation: Body size and the modifications of the male elytra are subject to remarkable intraspecific variation. The elevations on the male elytra are fully pronounced only in the holotype, weakly pronounced in one, barely noticeable in two, and absent in three males.

Comparative notes: This species is characterized particularly by the modifications of the male elytra, the shapes of the male and female tergites VIII, and above all by the conspicuous morphology of the aedeagus and the distinctive shape of the spermatheca. For additional characters separating it from the sympatric and syntopic D. palata see the comparative notes in the following section.

Distribution and natural history: The known distribution is confined to two localities in West Yunnan. The specimens were collected on and near the bank of a stream and near a pond at altitudes of 1900 and $2070 \mathrm{~m}$, in one locality together with $D$. palata. Two paratypes are slightly teneral.

\section{Drusilla (Drusilla) palata spec. nov.}

(Figs 26-33)

Type material: Holotype $0^{\star}$ : “CHINA (Yunnan) Dali Bai Aut. Pref., Wuliang Shan, 20 km NW Weishan 1900 m (creek valley, under bank vegetation, stones, gravel) $25^{\circ} 19^{\prime} 58^{\prime \prime N}, 100^{\circ} 07^{\prime} 59^{\prime \prime E}, 17 . I X .2009$ D.W. Wrase [58] / Holotypus o Drusilla palata spec. nov. det. V. Assing 2015" (cAss).

Paratypes: $2 \sigma^{\star} o^{\star}$ : "CHINA (Yunnan) Dali Bai Aut. Pref., Hóu Hé river bank, $10 \mathrm{~km} \mathrm{~S}$ Weishan, $1650 \mathrm{~m}$ (in gravel close to water) $25^{\circ} 08^{\prime} 36.8^{\prime \prime} \mathrm{N}, 100^{\circ} 19^{\prime} 34.5^{\prime \prime} \mathrm{E}, 14 . \mathrm{IX} .2009$ D.W. Wrase [53]" (cSch).

Etymology: The specific epithet is an adjective derived from the Latin noun pala (shovel) and alludes to the conspicuous shape of the posterior projection of the male sternite VIII.
Description: Body length 5.1-6.3 mm; length of forebody 2.5-2.6 mm. Coloration: head, pronotum, and abdomen blackish; elytra dark-yellowish, with the scutellar region and an extensive lateral spot infuscate; legs uniformly pale-yellowish; antennae blackish-brown; maxillary palpi reddish to dark-brown, with the terminal palpomere yellow.

Head (Fig. 26) approximately 1.2 times as broad as long; dorsal surface with median portion flattened or shallowly impressed; punctation fine to moderately coarse and of variable density, sparse to dense; interstices without microsculpture and glossy. Eyes large and bulging, much longer than distance from posterior margin of eye to posterior constriction of head. Antenna (Fig. 27) $2.1 \mathrm{~mm}$ long; antennomeres III-X gradually and very weakly increasing in width; preapical antennomeres weakly transverse.

Pronotum (Fig. 26) 1.06-1.10 times as broad as long and 1.06 times as broad as head, broadest at anterior angles; posterior angles obtusely marked; posteriorly with a very small and indistinct impression; midline with narrow, deep, and sharply delimited furrow extending from posterior impression cephalad, but not reaching anterior margin of pronotum; punctation dense and coarse, not granulose; interstices without microsculpture and glossy. Elytra (Fig. 26) approximately 0.9 times as long as pronotum; humeral angles marked; punctation dense, similar to that of pronotum. Hind wings fully developed. Metatarsomere I shorter than the combined length of II-IV. Abdomen (Fig. 28) narrower than elytra; tergites IIIVII without sexual dimorphism; anterior impressions of tergites III-V and posterior margins of tergites III-VII with fine punctation, remainder of tergal surfaces with very sparse punctation; posterior margin of tergite VII with palisade fringe.

$\sigma^{7}$ : pronotum (Fig. 26) with extensive and pronounced median impression in posterior half; tergite VIII (Fig. 29) strongly transverse and with pronounced posterior concavity of nearly semi-circular shape; sternite VIII (Fig. 30) of highly distinctive shape, posteriorly with a pronounced truncate projection and with acutely projecting posterior angles; median lobe of aedeagus (Figs 31-32) $0.9 \mathrm{~mm}$ long and of weakly derived morphology, with pronounced crista apicalis, and with short flagellum and additional dark structures in internal sac; paramere (Fig. 33) approximately $0.75 \mathrm{~mm}$ long, only slightly shorter than median lobe.

o: : unknown.

Comparative notes: From the externally (size, coloration, proportions, punctation) similar and syntopic D. flagellata, this species is readily distinguished by the uniformly yellowish legs, the deeper impression on the male pronotum, the slightly different coloration of the elytra, the absence of a sexual dimorphism of the elytra, the competely different shapes of the male tergite and sternite VIII, the completely different morphology of the median lobe of the aedeagus, and the distinctly larger and differently shaped paramere. 
Distribution and natural history: Drusilla palata is known from two localities in West Yunnan. The specimens were collected from gravel on the banks of a stream and a river at altitudes of 1650 and $1900 \mathrm{~m}$, in one locality together with $D$. flagellata.

\section{Drusilla (Drusilla) yunnanensis PACE, 1993}

(Figs 34-45)

Material examined: China: Yunnan: $30^{-1} o^{-1}, 2+q$, Yunnan, mountains S Jianshui, $23^{\circ} 25^{\prime} \mathrm{N}, 102^{\circ} 51^{\prime} \mathrm{E}$, $1810 \mathrm{~m}$, secondary forest margin, litter and various debris sifted, 22.VIII.2014, leg. Assing \& Schülke (cSch, cAss).
Comment: In the original description, which is based on a male holotype from "Yunnan, Dali" and a female paratype from "Yunnan, Kunming", PACE (1993) describes the coloration as "...; uriti liberi primo e secondo giallo-rossicci; antenne brune con i due articoli basali di un rossiccio scuro; zampe gialle con ginocchia medie e posteriori di un rossiccio scuro". The other characters specified in the very short original description are too vague to be of taxonomic use. Despite the differences in the coloration (see the redescription below), the examined material is undoubtedly conspecific with the holotype, as can be inferred from the identical shape of the median lobe of the aedeagus (compare Figs 40-41 and figures 144-145 in PACE 1993). The type specimens

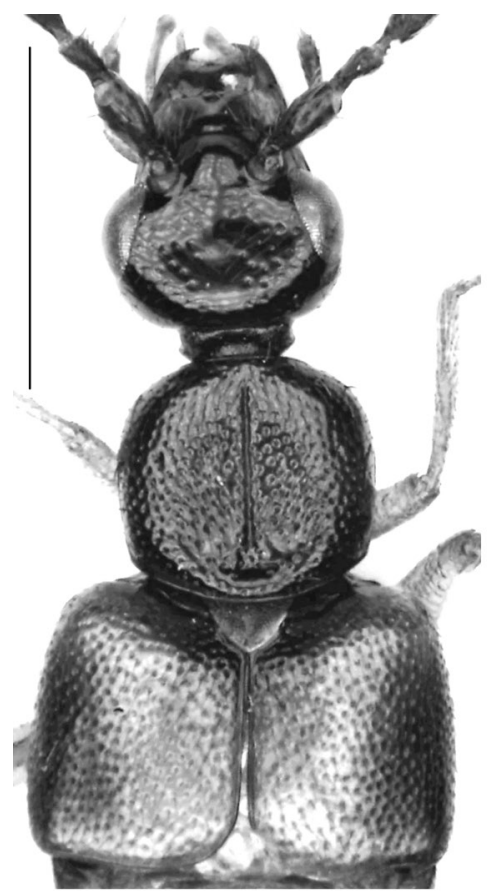

26

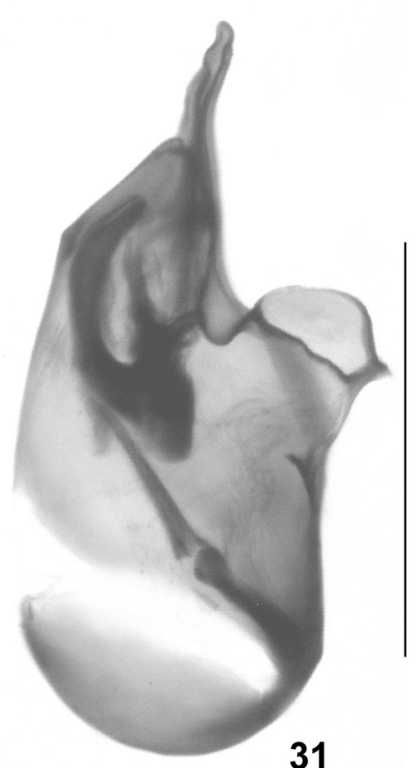

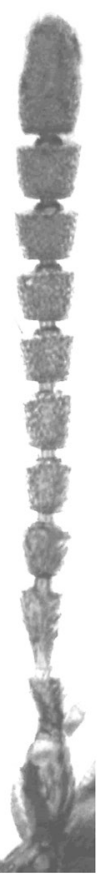

27

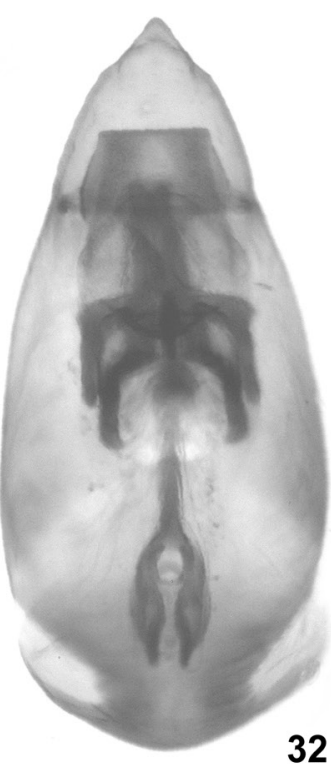

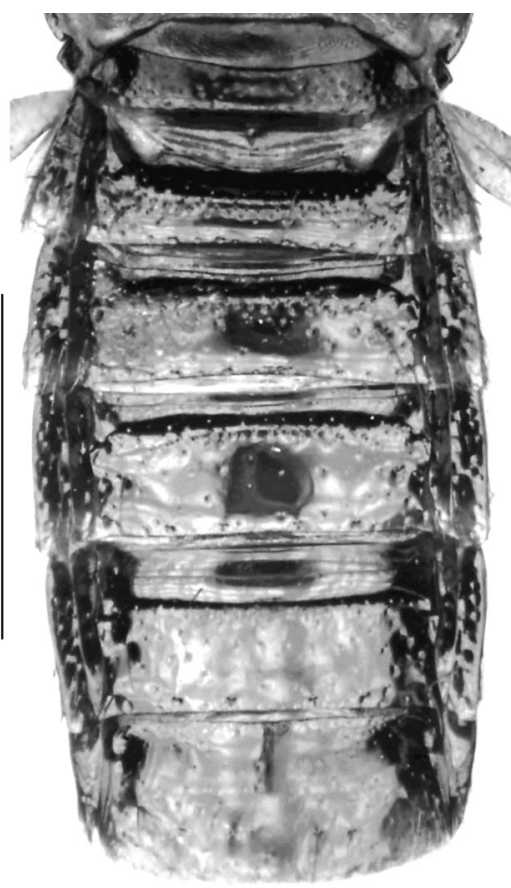

28
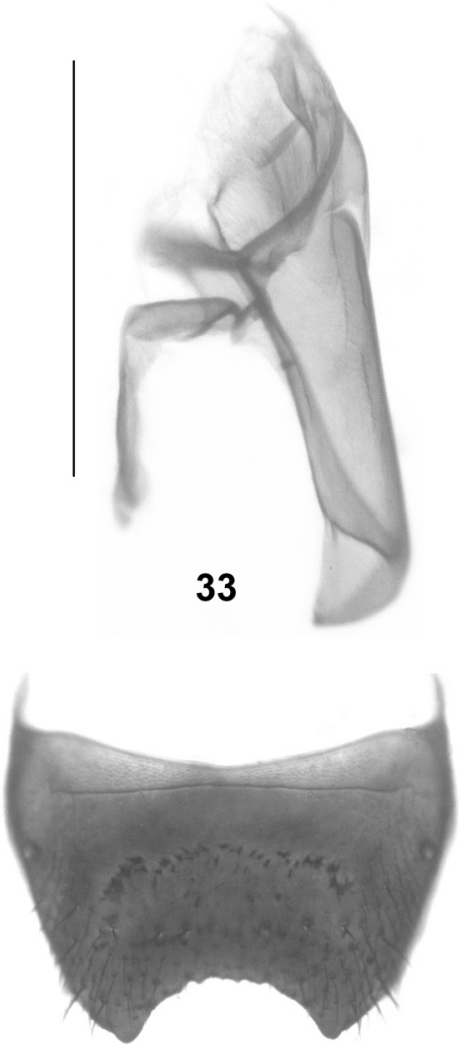

29

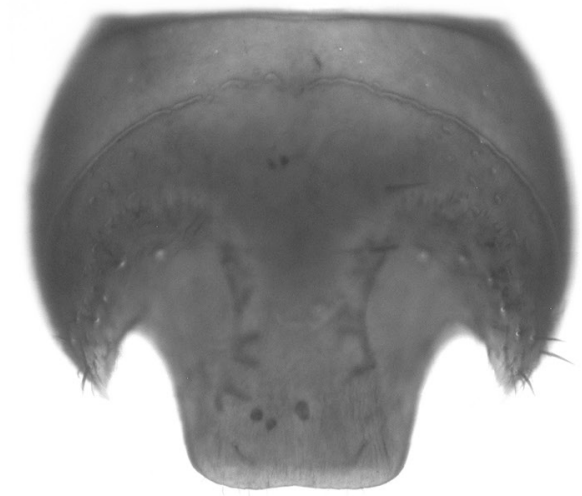

30

Figs 26-33:Drusillapalata spec. nov.: maleforebody (26); antenna (27); male abdomen (28); male tergite VIII (29); male sternite VIII (30); median lobe of aedeagus in lateral and in ventral view (31-32); paramere (33). Scale bars: 26-28: $1.0 \mathrm{~mm}$; 29-33: 0.5 mm. 
may be teneral. The illustration of the spermatheca (PACE 1993: figure 141) of the paratype is misleading. In order to allow a reliable identification of this species, a redescription and new illustrations are provided.

Redescription: Body length 4.8-6.3 mm; length of forebody $2.3-2.6 \mathrm{~mm}$. Coloration: body black, elytra with or without faint bronze hue; legs uniformly yellowish, rarely with the femoral apices indistinctly darker; antennae black, with antennomeres I-III slightly paler blackishbrown; maxillary palpi pale-brown to dark-brown, with the terminal palpomere yellow.

Head (Figs 34-35) approximately 1.1 times as broad as long; punctation of dorsal surface subject to sexual dimorphism; interstices without microsculpture and glossy. Eyes large and bulging, much longer than distance from

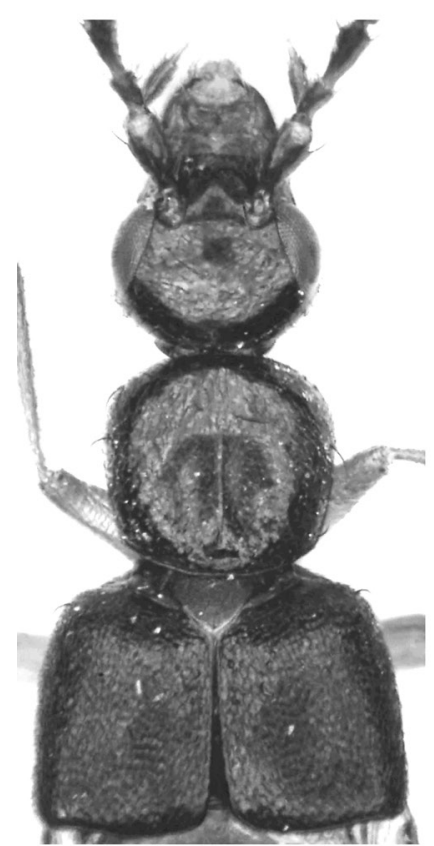

34

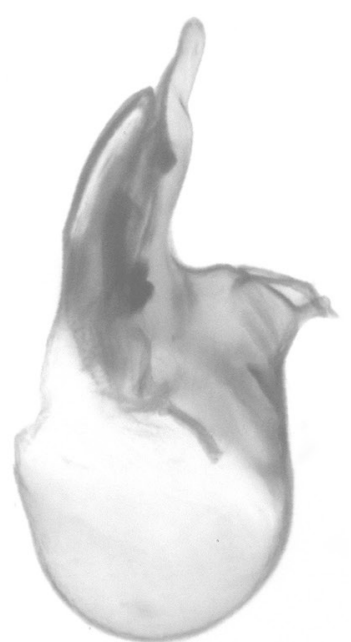

40

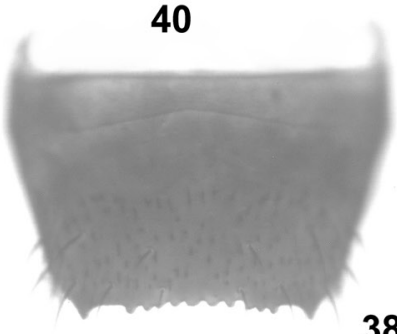

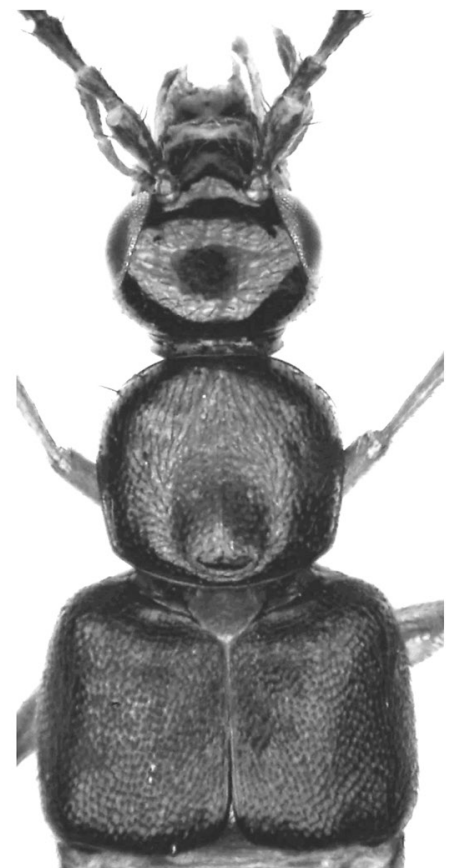

35

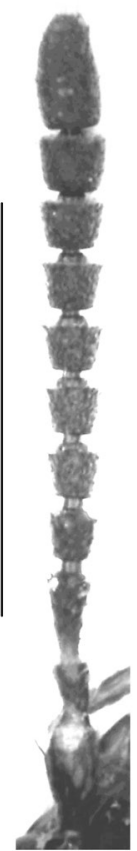

36

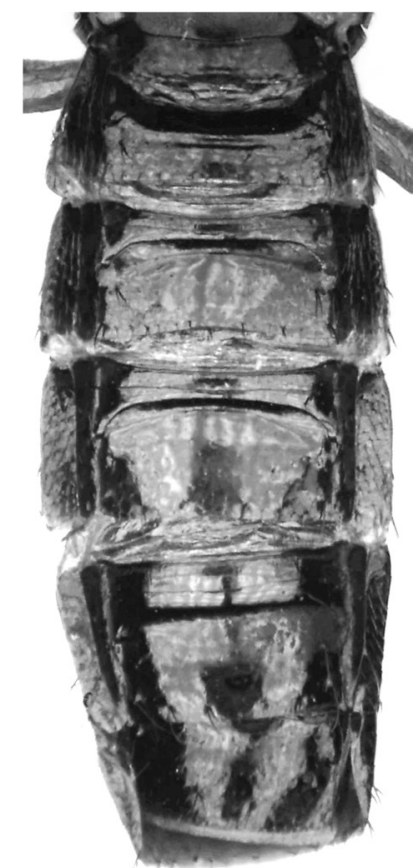

37

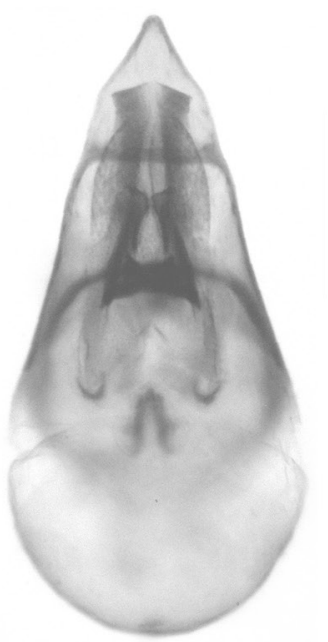

41

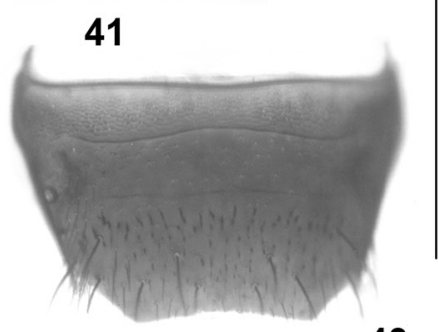

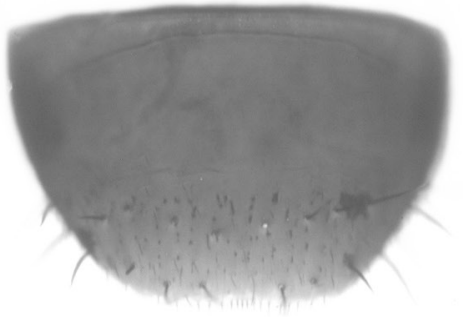

44
42

43

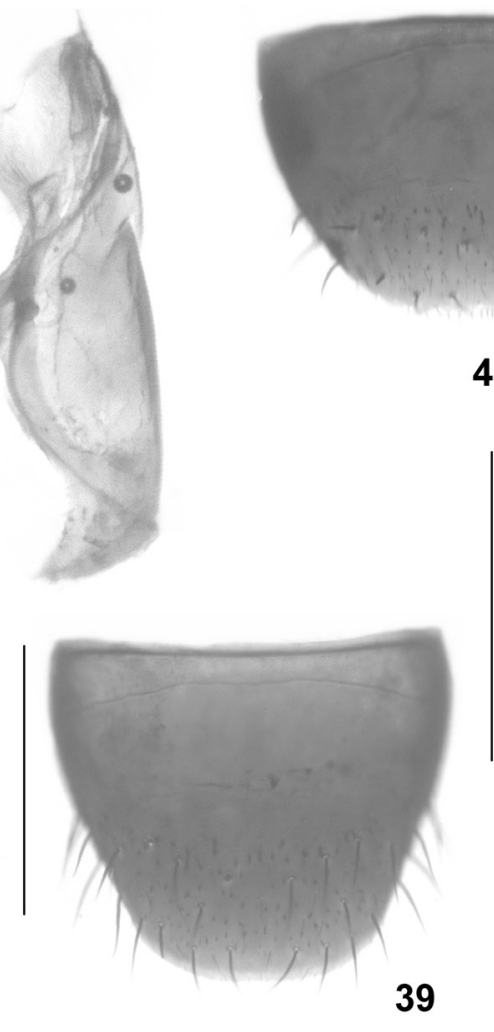

39

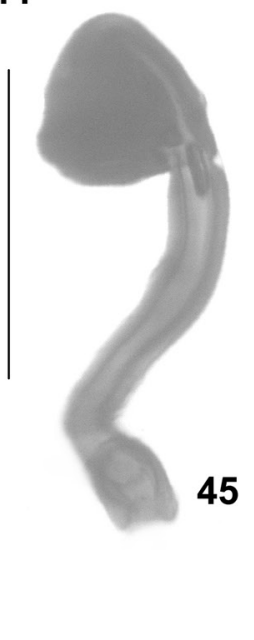

Figs 34-45: Drusilla yunnanensis: male forebody (34); female forebody (35); antenna (36); female abdomen (37); male tergite VIII (38); male sternite VIII (39); median lobe of aedeagus in lateral and in ventral view (40-41); paramere (42); female tergite VIII (43); female sternite VIII (44); spermatheca (45). Scale bars: 34-37: $1.0 \mathrm{~mm}$; 38-39, 43-44: 0.5 mm; 40-42, 45: 0.2 mm. 
posterior margin of eye to posterior constriction of head. Antenna (Fig. 36) 2.0-2.1 mm long; antennomeres III-X gradually increasing in width; antennomeres VI-X transverse.

Pronotum (Figs 34-35) approximately 1.06 times as broad as long and 1.10-1.13 times as broad as head, broadest at anterior angles; posterior angles obtusely marked; posteriorly with small transverse impression; midline with very fine line extending cephalad from posterior impression, but not reaching anterior margin of pronotum; punctation sexually dimorphic; interstices without microsculpture and glossy.

Elytra (Figs 34-35) approximately 0.9 times as long as pronotum; humeral angles marked; punctation very dense, not very coarse, but much more distinct than that of pronotum. Hind wings fully developed. Metatarsomere I shorter than the combined length of II-IV.

Abdomen (Fig. 37) approximately as broad as elytra; tergites III-VII without sexual dimorphism; anterior impressions of tergites III-V and anterior portion of tergite VI impunctate; tergite III with moderately sparse to very sparse fine punctation; tergites IV-VI with setiferous punctures at posterior margin, remainder of tergal surfaces with very sparse and minute punctures; tergite VII with sparse and fine punctation, posterior margin with palisade fringe.

$\sigma^{*}$ : postero-median portion of head with moderately sparse, somewhat coarser punctures, remainder of dorsal surface with fine and sparse punctation; pronotum (Fig. 34) with extensive, but not very deep median impression in posterior half; punctation of pronotum fine and moderately dense, postero-lateral edges of postero-median impression with coarser granulose sculpture; tergite VIII (Fig. 38) strongly transverse and with distinctly serrate posterior margin, postero-lateral angles with more pronounced tooth on either side; sternite VIII (Fig. 39) weakly transverse, posterior margin weakly convex in the middle; median lobe of aedeagus (Figs 40-41) relatively small, approximately $0.65 \mathrm{~mm}$ long; paramere $0.6 \mathrm{~mm}$ long and shaped as in Fig. 42.

o: head (Fig. 35) with extemely fine, barely noticeable sparse punctation; pronotum (Fig. 35) somewhat depressed in posterior half, but without distinct impression (aside from the small posterior transverse impression); punctation of pronotum rather dense and fine, but more distinct than that of head; tergite VIII (Fig. 43) strongly transverse, posterior margin weakly concave in the middle; sternite VIII (Fig. 44) distinctly shorter and more transverse than that of male, posterior margin weakly convex; spermatheca $0.33 \mathrm{~mm}$ long, with large, apically truncate, and strongly sclerotized distal portion (Fig. 45).

Comparative notes: Among the Drusilla species recorded from China, D. yunnanensis is characterized particularly by the dense punctation of the elytra, the fine punctation of the head and the pronotum, the impunctate anterior impressions of the abdominal tergites III- $\mathrm{V}$, the male secondary sexual characters, the shape of the female tergite VIII, the morphology of the median lobe of the aedeagus, and the shape of the spermatheca.

Distribution and natural history: The currently known distribution is confined to three localities in Yunnan. Maruyama \& Kishimoto (2002a) collected the species from trails of Lasius (Dendrolasius) spathepus WHEELER, 1910 and L. (D.) capitatus KuzNETsov-Ugamsky, 1927. The examined specimens were sifted from litter and various debris at the margin of a secondary mixed forest at an altitude of $1810 \mathrm{~m}$.

\subsection{Pella StePHENS, 1835}

\section{Pella limbata (PAYKULL, 1789)}

Material examined: Ukraine: 5 exs., Crimea, Alushta distr., m. Kazu-Kaya, 30.IV.2009, leg. Gontarenko (cGon, cAss).

Comment: The trans-Palaearctic distribution of $P$. limbata ranges from West Europe to East Siberia (SMETANA 2004).

\section{Pella reuteri Assing, 2008}

(Figs 46-47)

Material examined: Iraq: $1 \mathrm{o}^{*}$, Amedi env., $1200 \mathrm{~m}$, V.2007, leg. Reuter (cFel).

Comment: The original description of this species is based on two females from northern Iraq (Assing 2008b). The male sexual characters were previously unknown. Based on the above male, they are as follows: posterior margin of tergite VIII weakly concave in the middle; posterior margin of sternite VIII broadly convex; median lobe of aedeagus $0.72 \mathrm{~mm}$ long and shaped as in Figs 46-47.

The male sexual characters are highly similar to those of P. ruficollis (GRIMM, 1845), except for the slightly longer ventral process of the aedaegus.

\section{Pella laeviceps (EPPELSHEIM, 1880)}

Material examined: Russia: 5 exs., N-Caucasus, $80 \mathrm{~km} \mathrm{SW}$ Maykop, 950 m, 6.-9.V.1991, leg. Medvedev (NHMB, cAss).

Comment: The distribution of this species is confined to the Caucasus region, from Turkey and Armenia across Georgia to South Russia and Azerbaijan (SMEtAnA 2004).

\section{Pella lugens (GRAVENHORST, 1802) (Figs 48-49)}

Material examined: China: Gansu: 4 exs. [1 teneral], Lenglong Ling mountains, $60 \mathrm{~km}$ NNW Honggu, Jin Sha 
Gorge, $36^{\circ} 52^{\prime} \mathrm{N}, 102^{\circ} 39^{\prime} \mathrm{E}, 2330 \mathrm{~m}$, mixed forest, litter and moss sifted, 12.VII.2011, leg. Schülke (cSch, cAss).

Comment: The previously known distribution of $P$. lugens was confined to the West Palaearctic region (including Middle Asia) (Maruyama 2006). The above specimens represent the first record from the East Palaearctic region east of Middle Asia and considerably expand the range eastwards. The median lobe of the aedeagus of the material from Gansu is illustrated in Figs 48-49.

Pella cooterorum MaruYama, 2006

(Figs 50-57)

Material examined: China: Gansu: $20^{\top} o^{\top}$ [1 teneral], mountains SE Longnan, $33^{\circ} 11^{\prime} \mathrm{N}, 105^{\circ} 14^{\prime} \mathrm{E}, 2130 \mathrm{~m}$,

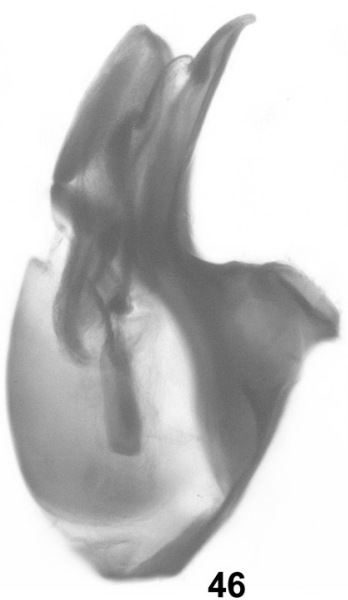

46

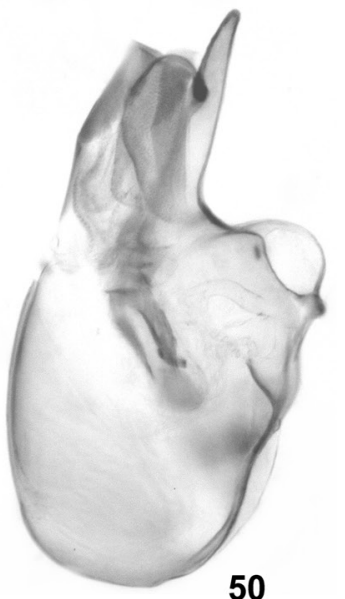

50
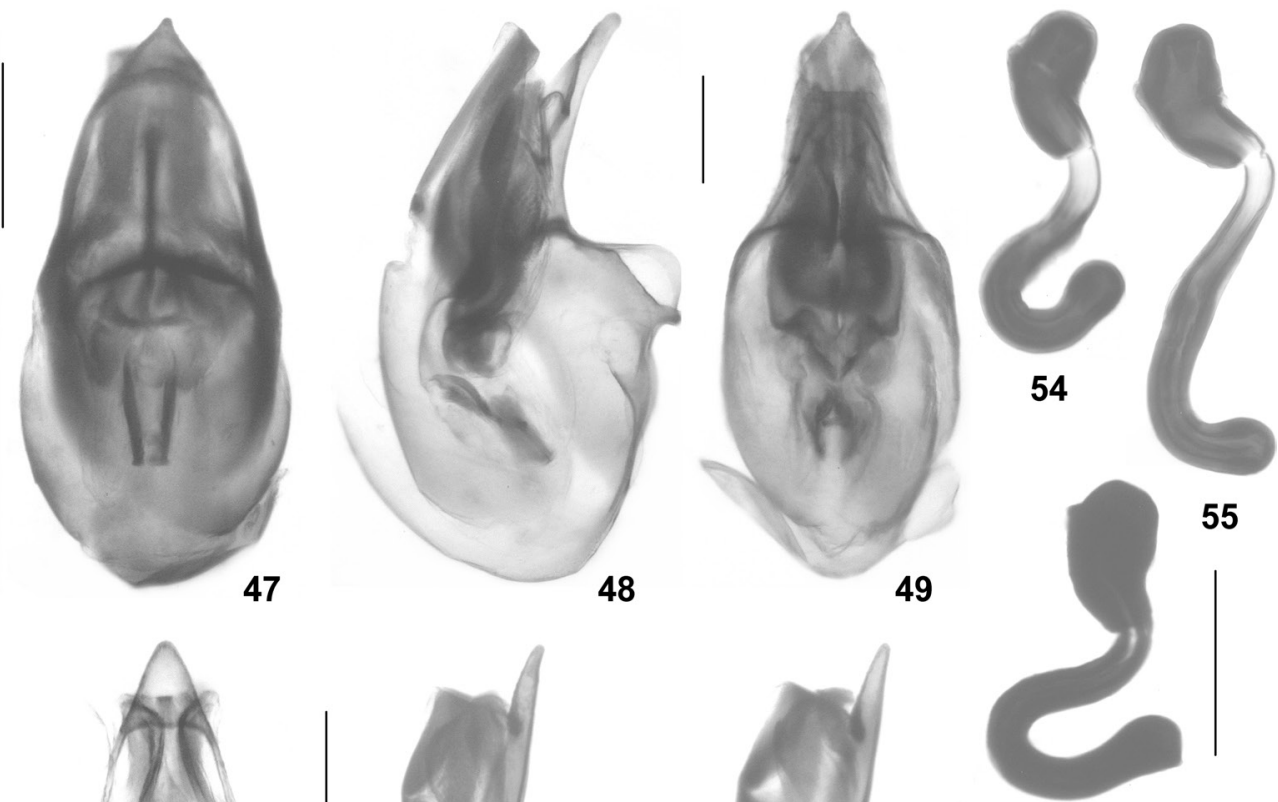

57

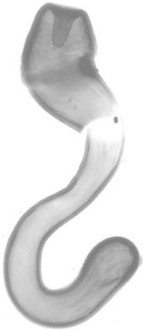

56

52

53

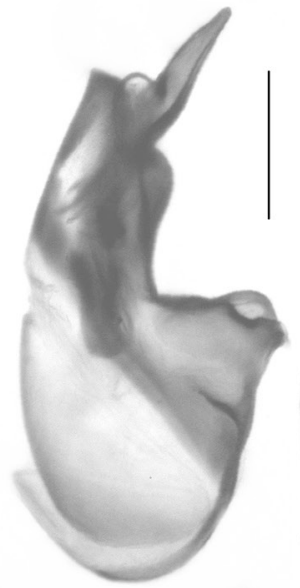

58

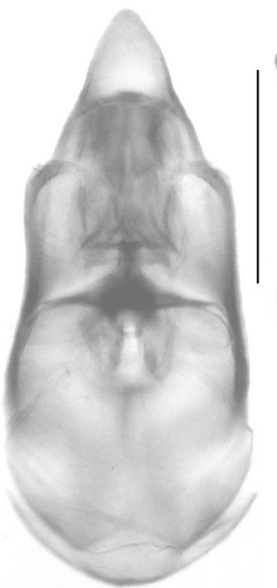

59

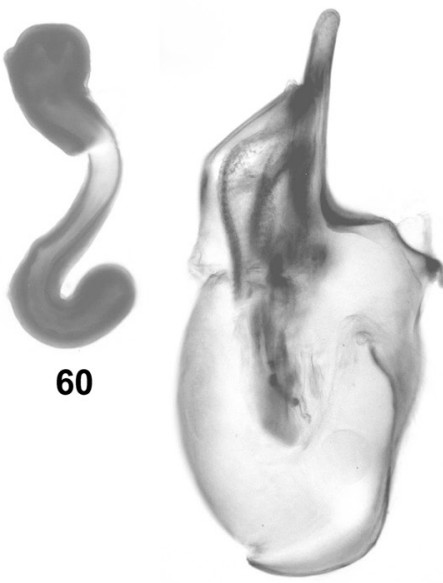

61

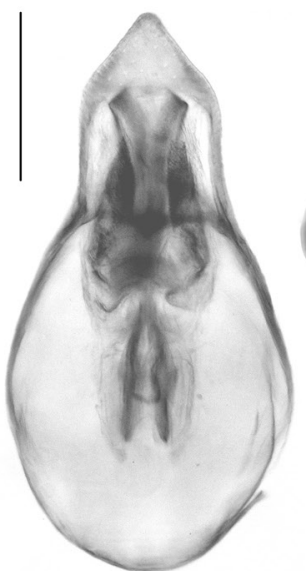

62

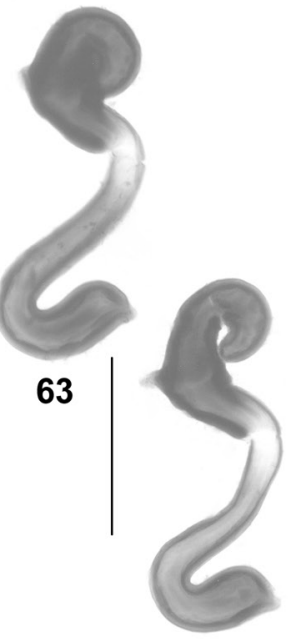

64

Figs 46-64: Pella reuteri (46-47), P. lugens from Gansu (48-49), P. cooterorum from Qinghai (50-51, 54), Gansu (55), Yunnan: Dongchuan env. $(52,56)$, and Yunnan: Kunming env. $(53,57)$, P. jureceki from Gansu (58-60), and P. zhoui from Qinghai (61-64): median lobe of aedeagus in lateral and in ventral view $(46-53,58-59,61-62)$; spermatheca $(54-57,60,63-64)$. Scale bars: $0.2 \mathrm{~mm}$. 
N-slope with scree, stony soil sifted, 7.VIII.2012, leg. Assing \& Wrase (cAss, cSch); 7 exs., Lenglong Ling mountains, $60 \mathrm{~km}$ NNW Honggu, Jin Sha Gorge, $36^{\circ} 52^{\prime} \mathrm{N}, 102^{\circ} 39^{\prime} \mathrm{E}, 2330 \mathrm{~m}$, mixed forest, litter and moss sifted, 12.VII.2011, leg. Schülke (cSch, cAss); 2 exs., same data, but 14.-15.VII.2011 (cSch, cAss); 2 exs., same data, but pitfall traps, 12.-13.VII.2011, leg. Wrase (cSch, cAss). Qinghai: 20 exs., Daban Shan, $62 \mathrm{~km}$ NNW Honggum, 36 $51^{\prime} \mathrm{N}, 102^{\circ} 37^{\prime} \mathrm{E}, 2240 \mathrm{~m}$, stream valley with mixed forest, pitfall traps, 26.-29.VI.2011, leg. Wrase (cSch, cAss); 31 exs., same data, but 11.-15. VII.2011 (cSch, cAss); 10 exs., same data, but loamy slope, 26. \& 29.VI.2011 (cSch, cAss); 13 exs., same data, but 2240-2350 m, litter and moss sifted, 10.VII.2011, leg. Schülke (cSch, cAss); 8 exs., same data, but 26.VI.2011, leg. Schülke (cSch, cAss); 1 ex., same data, but 26.VI.-10. VII.2011, leg. Wrase (cAss); 4 exs., same data, but 2275 m, litter sifted, 10.VI.2011, leg. Wrase (cSch, cAss); 1 ex., same data, but 26.VI.2011 (cAss); 1 ex., Daban Shan, $80 \mathrm{~km}$ NNW Honggu, 36 $59^{\prime} \mathrm{N}, 102^{\circ} 26^{\prime} \mathrm{E}, 2350-2450 \mathrm{~m}$, stream valley with mixed forest, litter and moss sifted, 27.VI.2011, leg. Schülke (cSch). Yunnan: $3 \sigma^{\star} \sigma^{\star}, 1$ 우, mountains W Dongchuan, Sedan Snow Mountain Scenic Resort, $26^{\circ} 06^{\prime} \mathrm{N}, 102^{\circ} 55^{\prime} \mathrm{E}, 2620 \mathrm{~m}$, secondary pine forest, litter, moss, and roots of herbs sifted, 14.VIII.2014, leg.

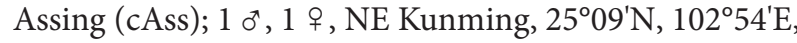
$2280 \mathrm{~m}$, secondary pine forest, with scattered old alder, litter sifted, 11.VIII.2014, leg. Assing \& Schülke (cSch).

Comment: This species was previously known only from the Chinese provinces Beijing and Yunnan (Maruyama 2006). The above specimens are brachypterous, with the hind wings of strongly reduced length (just projecting beyond posterior margin of elytra).

The specimens from Yunnan are distinguished from those from Qinghai and Gansu by an on average more transverse pronotum. Moreover, remarkable variation in the shape of the spermatheca was observed (Figs 54-57). Since no additional distinguishing characters were found and since the median lobe of the aedeagus is practically identical (Figs 50-53), however, these differences are interpreted as intraspecific variation.

Many of the specimens from Gansu and Qinghai were collected with pitfall traps with vinegar.

\section{Pella jureceki (Dvǒ̌́́́k, 1981) \\ (Figs 58-60)}

Material examined: China: Gansu: 57 exs., Lenglong Ling

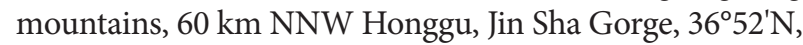
$102^{\circ} 39^{\prime} \mathrm{E}, 2330 \mathrm{~m}$, mixed forest, litter and moss sifted, 12.VII.2011, leg. Schülke \& Wrase (cSch, cAss); 3 exs., same data, but 14.-15.VII.2011 (cSch, cAss); 6 exs., same data, but pitfall traps, 12.-13.VII.2011, leg. Wrase (cSch, cAss). Qinghai: 1 ex., Daban Shan, 62 km NNW Honggum, $36^{\circ} 51^{\prime} \mathrm{N}, 102^{\circ} 37^{\prime} \mathrm{E}, 2240-2350 \mathrm{~m}$, litter and moss sifted, 10.VII.2011, leg. Schülke (cSch); 49 exs., same data, but 26.VI.2011, leg. Schülke (cSch, cAss); 9 exs., same data, but $2350 \mathrm{~m}$ (cSch, cAss); 26 exs., same data, but $2275 \mathrm{~m}$, litter sifted, 26.VI.2011, leg. Wrase (cSch, cAss).

Comment: Pella jureceki was previously known from the Russian Far East, Korea, and the Chinese province Beijing. According to the redescription by MARUYAMA (2006), the species is "blackish brown in ground colour", but all the examined specimens are completely black. The primary sexual characters of the material from Gansu are illustrated in Figs 58-60. The specimens listed above were collected together with $P$. cooterorum (in all localities), in Qinghai also with P. zhoui and in Gansu with P. lugens. Unlike P. cooterorum, P. jureceki was almost exclusively sifted from leaf litter.

\section{Pella zhoui Maruyama, 2006}

(Figs 61-64)

Material examined: China: Qinghai: 6 exs., Daban Shan, $62 \mathrm{~km}$ NNW Honggum, 36 $51^{\prime} \mathrm{N}, 102^{\circ} 37^{\prime} \mathrm{E}, 2275 \mathrm{~m}$, stream valley with mixed forest, litter and moss sifted, 26.VI.2011, leg. Wrase (cSch, cAss); 1 ex., same data, but 2230-2250 m, leg. Schülke (cSch); 1 ex., same data, but $2350 \mathrm{~m}$, leg. Schülke (cSch).

Comment: Pella zhoui was previously recorded from the Chinese province Beijing and from the Russian Far East (Maruyama 2006). The above specimens were collected together with $P$. cooterorum and $P$. jureceki. Their primary sexual characters are illustrated in Figs 61-64.

\section{Pella japonica (SHARP, 1888)}

Material examined: Japan: 3 exs., Hokkaido, Sapporo env., Nopporo virgin forest, 5.VI.2011, leg. Lackner (cAss).

Comment: This rather widespread species has been recorded from Japan, the Russian Far East and Korea (Maruyama 2006).

\subsection{Amaurodera FAUVEL, 1905}

\section{Amaurodera angularis spec. nov. (Figs 65-72)}

Type material: Holotype $o^{\top}$ : "INDIA W. Bengal, Darjeeling distr., Teesta-Rangpo 350 m, Besuchet-Löbl 12.X.78 / Holotypus o Amaurodera angularis spec. nov., det. V. Assing 2015" (MHNG).

Paratypes: $2 o^{\top} o^{*}$ [1 teneral]: same data as holotype (MHNG, cAss); 1 ㅇ: "INDIA W. Bengal, Darjeeling distr., Sevoke 200 m, 7.X.78 Besuchet-Löbl" (cAss). 
Comment: The specific epithet (Latin, adjective: angled) alludes to the shape of the ventral process of the aedeagus in lateral view.

Description: Body length 3.8-4.2 mm; length of forebody $1.85-2.05 \mathrm{~mm}$. Coloration: head reddish; pronotum reddish to reddish-brown; elytra reddish; abdomen yellowish, with segments VI-VII more or less distinctly and more or less extensively infuscate; legs and antennae yellowish. Head (Fig. 65) as long as broad or weakly oblong, broadest across eyes, and with sexual dimorphism; punctation sparse and extremely fine; interstices with or without very shallow, nearly obsolete microreticulation. Eyes $0.7-0.8$ times as long as the distance from posterior margin of eye to posterior constriction of head. Antenna (Fig. 66) approximately $2.4 \mathrm{~mm}$ long and very slender. Pronotum (Fig. 65) 1.30-1.35 times as long as broad and approximately 1.05 times as broad as head; dorsal surface matt; dorsal and lateral surface meeting at an angle posteriorly; microreticulation reaching lateral carinae only posteriorly; narrow median furrow of reduced, but variable length, extending along anterior half to anterior four fifths, far from reaching anterior or posterior margins.

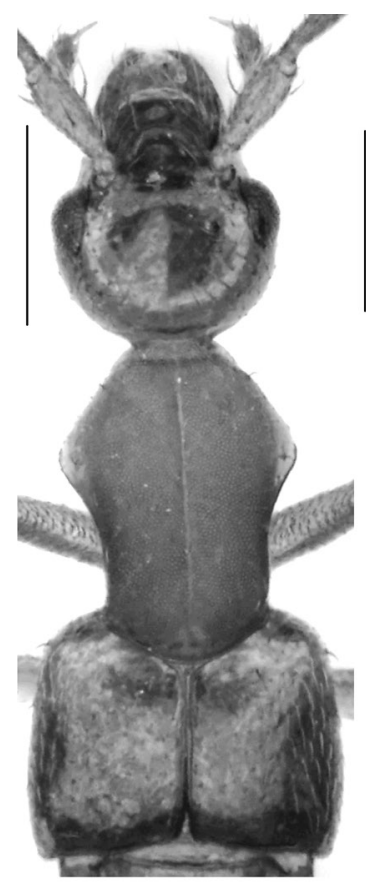

65

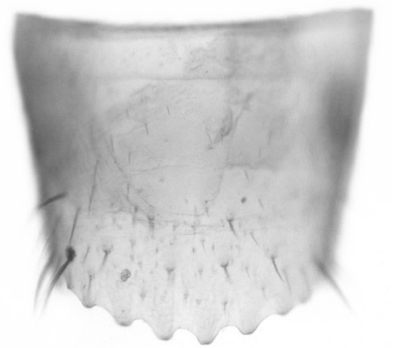

68

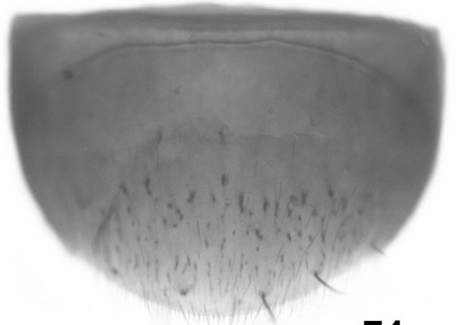

74

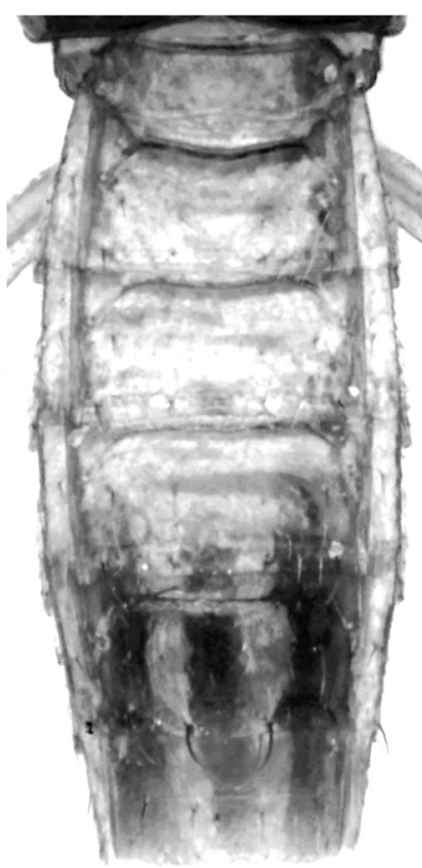

67

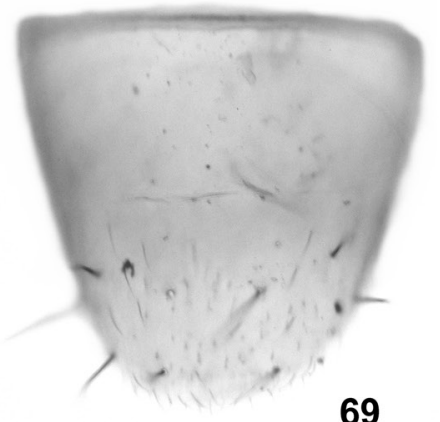

69

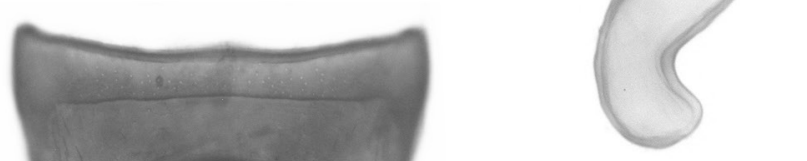

72

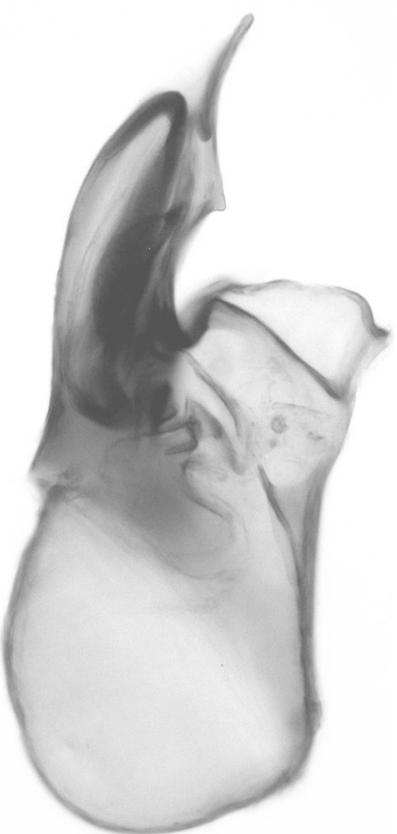

70

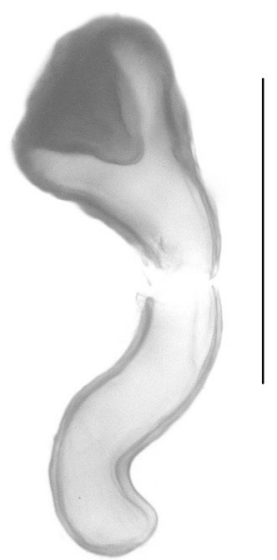

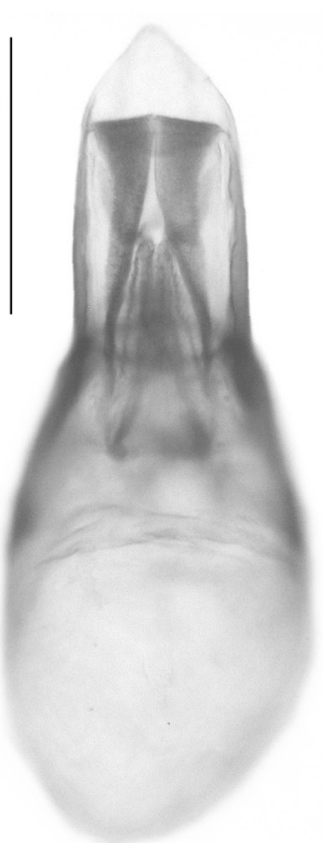

71

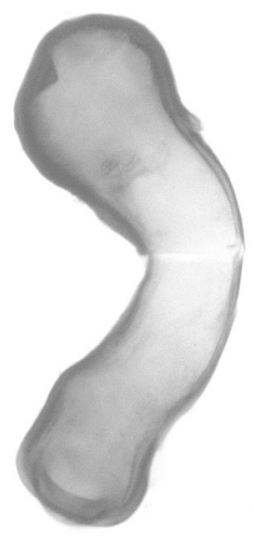

75

Figs 65-75: Amaurodera angularis spec. nov. (65-72) and A. ilamica (73-75): male forebody (65); antenna (66); abdomen (67); male tergite VIII (68); male sternite VIII (69); median lobe of aedeagus in lateral and in ventral view (70-71); spermatheca $(72,75)$; female tergite VIII (73); female sternite VIII (74). Scale bars: 65-67: $1.0 \mathrm{~mm}$; 68-75: 0.2 mm. 
Elytra (Fig. 65) approximately 0.55 times as long as pronotum; punctation sparse and extremely fine; pubescence whitish and depressed. Hind wings present. Metatarsomere I longer than combined length of II and III, but shorter than combined length of II-IV.

Abdomen (Fig. 67) narrower than elytra; tergites III-VI impunctate except for some setiferous punctures at posterior margin and a median pair of setiferous punctures bearing long brown setae; posterior margin of tergite VII with palisade fringe; posterior margin of tergite VIII (Fig. 68) convex and denticulate.

$0^{*}$ : dorsal surface of head with distinct and extensive impression (Fig. 65); sternite VIII (Fig. 69) nearly as long as broad and with weakly convex posterior margin; median lobe of aedeagus (Figs 70-71) $0.6 \mathrm{~mm}$ long; ventral process strongly angled in lateral view; paramere $0.5 \mathrm{~mm}$ long.

우 : surface of head not impressed; spermatheca as in Fig. 72.

Comparative notes: This species is distinguished from other species of the A. veluticollis group (see Assing 2003) particularly by the conspicuous shape of the ventral process of the aedeagus and by the sexual dimorphism of the head. It additionally differs from the sympatric A. cameroni by the shorter median furrow of the pronotum, the longer elytra, and the differently shaped spermatheca (A. cameroni: spermatheca proximally truncate).

The new species is distinguished from A. veluticollis (Motschulsky, 1858), whose male sexual characters are still unknown and whose original description is based on an unspecified number of syntypes from "Indes orientales" (probably Burma today), by the different shape and sculpture of the pronotum (A. veluticollis: antero-lateral projections less pronounced; dorsal and lateral surfaces posteriorly meeting at a more pronounced angle; microreticulation extending to lateral carinae), the shorter median sulcus on the pronotum, and the differently shaped apical cuticular intrusion of the spermatheca. The general shape of the spermatheca is more or less similar also in other species of the A. veluticollis group, e.g., A. thailandensis PACE, 1986 and A. birmana PACE, 1986. For illustrations of $A$. veluticollis, A. cameroni, and other Himalayan representatives of the genus see Assing (2003, 2005d, 2006a, 2010).

Distribution and natural history: The known distribution is confined to two localities in Darjeeling district, West Bengal province, North India. The type specimens were collected at low altitudes (200 and $350 \mathrm{~m}$ ), in one locality together with A. cameroni. One of the paratypes is teneral.

\section{Amaurodera smetanai PACE, 1992}

Amaurodera yaoana PACE, 1992: 257 f.; syn. nov.

Material examined: China: $1 \sigma^{\star}$, Yunnan, Xishuanbanna, 60 km N Jinghong, Guanping env., 1000 m, 19.-27.I.2003, leg. Murzin (cAss); 2 exs., Hainan, Limu Shan, forest above forest administration centre, $19^{\circ} 11^{\prime} \mathrm{N}, 109^{\circ} 44-45^{\prime} \mathrm{E}$,
650-900 m, secondary forest, sifted from moist leaf litter along trail, 6.V.2011, leg. Fikáček (NMP, cAss).

Comment: Amaurodera smetanai was originally described from East Nepal and subsequently twice recorded from the Chinese island Hainan (Assing 2003; PACE 2012; YAN \& Li 2015).

The original description of A. yaoana is based on three females from two localities in Thailand. Based on the distinctive shape of the spermatheca, these specimens are conspecific with the widespread A. smetanai. The description of A. smetanai was published in March, whereas the exact date of the publication of the description of A. yaoana is not indicated, so that the latter is the junior synonym.

The known distribution of A. smetanai now ranges from Nepal across southern China (Yunnan, Hainan) to Thailand.

\section{Amaurodera cameroni Assing, 2003}

Material examined: India: West Bengal: $1 \sigma^{\star}$, Darjeeling District, Sevoke, 200 m, 7.X.1978, leg. Besuchet \& Löbl (MHNG).

Comment: The known distribution of A. cameroni extends from Uttarakhand to Assam (Assing 2003, 2005d, 2009).

\section{Amaurodera bomfordi (EPPELSHEIM, 1890)}

Material examined: India: Uttarakhand: 20 exs., NE Govind Ghat, road to Ghangaria, 9.-10.VI.2011, leg. Shavrin (cSha, cAss); 4 exs., $14 \mathrm{~km}$ E Uttarkashi, $30^{\circ} 45^{\prime} \mathrm{N}$, 78³4'E, $1450 \mathrm{~m}, 10 .-12 . I V .2012$, leg. Shavrin (cAss, cSha). Uttar Pradesh: 1 ex., Kumaon, Rangarh env., 2000 m, 9.X.1979, leg. Löbl (MHNG).

Nepal: 11 exs., Manaslu W Gupchi Danda, 2200-2300 m, 28.V.2006, leg. Schmidt (NME, cAss); 1 ex., Manaslu, E-slope, Machha Khola valley, Gumda to Lapsibot, $28^{\circ} 12^{\prime} \mathrm{N}, 84^{\circ} 50^{\prime} \mathrm{E}, 1500-1900$ m, 23.V.2006, leg. Schmidt (cAss); 1 ex., W-Dhaulagiri, Pelma Khola valley, $28^{\circ} 42^{\prime} \mathrm{N}$, $82^{\circ} 56^{\prime}$ E, 2400-2700 m, 17.IX.2012, leg. Schmidt (NME).

Comment: This species is widespread and the most common representative of the genus in the Himalayan region (Assing 2003, 2005d, 2006a, 2010). For a distribution map see Assing (2006a).

\section{Amaurodera soror CAMERON, 1939}

Material examined: India: Uttarakhand: 17 exs., Kosi river valley, $5 \mathrm{~km} \mathrm{~N}$ Ramnagar, $29^{\circ} 26^{\prime} \mathrm{N}, 7^{\circ} 08^{\prime} \mathrm{E}, 23 .-26 . I V .2012$, leg. Shavrin (cAss, cSha); 7 exs., left side of Kosi river, $5 \mathrm{~km}$ N Ramnagar, "N29*32 E79*149”, 19.-23.VI.2011, leg. 
Shavrin (cSha, cAss); 7 exs., $14 \mathrm{~km} \mathrm{E} \mathrm{Uttarkashi,} 30^{\circ} 45^{\prime} \mathrm{N}$, $78^{\circ} 34^{\prime} \mathrm{E}, 1450 \mathrm{~m}, 10 .-12 . I V .2012$, leg. Shavrin (cAss, cSha); 10 exs., $15 \mathrm{~km}$ SW New Tehri, $30^{\circ} 16^{\prime} \mathrm{N}, 78^{\circ} 22^{\prime} \mathrm{E}, 870 \mathrm{~m}$, 18.-20.IV.2012, leg. Shavrin (cSha, cAss); 4 exs., $10 \mathrm{~km}$ NW New Tehri, $30^{\circ} 27^{\prime} \mathrm{N}, 78^{\circ} 32^{\prime} \mathrm{E}, 1200$ m, 9.-10.IV.2012, leg. Anichtchenko \& Shavrin (cSha, cAss); 1 ex., Uttarkashi district, $14 \mathrm{~km} \mathrm{NW}$ New Tehri, 30²8' N, 78²1'E, $950 \mathrm{~m}$, 18.IV.2012, leg. Anichtchenko (cAss).

Uttar Pradesh: 1 ex., Garhwal, $16 \mathrm{~km}$ from Srinagar, 550 m, 29.X.1979, leg. Löbl (MHNG).

Nepal: 1 ex., S-Dhaulagiri, Phedi to Phalegaon, $28^{\circ} 28^{\prime} \mathrm{N}$, $83^{\circ} 21^{\prime} \mathrm{E}, 1100-1800 \mathrm{~m}, 9 . \mathrm{V} .2012$, leg. Schmidt (NME).

Comment: Like the preceding species, $A$. soror is widespread in the Himalayan region (Assing 2003, 2005d, 2006a, 2009). For a distribution map see Assing (2006a).

\section{Amaurodera silvana PACE, 1992}

Material examined: Nepal: 5 exs., SW-Dhaulagiri, Maraini, $28^{\circ} 31^{\prime} \mathrm{N}, 83^{\circ} 16^{\prime} \mathrm{E}, 2600 \mathrm{~m}, 24 . \mathrm{IX} .2012$, leg. Schmidt (NME, cAss)

Comment: This species is endemic to the Annapurna and Dhaulagiri ranges in Nepal (Assing 2003, 2005d, 2006a, 2009).

\section{Amaurodera coriacea Assing, 2003}

Material examined: Nepal: 3 exs., Manaslu, SE-slope, Gupchi Danda, $28^{\circ} 09^{\prime} \mathrm{N}, \quad 84^{\circ} 47^{\prime} \mathrm{E}, \quad 2900-3000 \mathrm{~m}$, 21.V.2006, leg. Schmidt (NME, cAss); 4 exs., Manaslu W Gupchi Danda, $28^{\circ} 09^{\prime} \mathrm{N}, 84^{\circ} 46^{\prime} \mathrm{E}, 2500-2800 \mathrm{~m}, 19 .-20 . \mathrm{V}$. 2006, leg. Schmidt (NME, cAss).

Comment: The known distribution of A. coriacea is confined to the Manaslu range (Assing 2003, 2005d, 2009).

\section{Amaurodera granata Assing, 2003}

Material examined: Nepal: 1 ex., Khandbari District, Induwa Khola valley, 2850 m, 15.IV.1984, leg. Smetana \& Löbl (MHNG).

Comment: Amaurodera granata has been recorded from Sankhua Saba, Khandbari, and Solukhumbu Districts in East Nepal (Assing 2003, 2005d).

\section{Amaurodera ilamica Assing, 2005}

(Figs 73-75)

Material examined: India: West Bengal: 4 exs., Darjeeling District, Algarah-Labha, 1900 m, 11.X.1978, leg. Besuchet \& Löbl (MHNG, cAss).
Comment: Previously, only the holotype from Ilam District, East Nepal, was known (Assing 2005d). The above specimens represent the first record from India. The previously unknown female sexual characters are illustrated in Figs 73-75.

\section{Amaurodera verrucosa Assing, 2003 and A. fulgens Assing, 2003}

Comment: In a recent article on miscellaneous aleocharines from Nepal, PACE (2013) synonymized A. verrucosa with A.martensi CoIffait, 1982 and A. fulgens with A. silvana PACE, 1992 stating that he did not see any differences in the aedeagal morphology, evidently because he had seen material of neither $A$. verrucosa nor $A$. fulgens. True, as emphasized by Assing (2003), A. fulgens is very similar to A. martensi, most likely its adelphotaxon, both in external and sexual characters, but it differs by constant differences of the aedeagal shape (ventral view) and in external characters (particularly elytral punctation). Moreover, the distributions of both species are allopatric. In the case of A. silvana and A. fulgens, the external and sexual characters distinguishing both species are so obvious and so numerous (see the key, descriptions, and illustrations in Assing (2003)) that considering these names synonyms appears somewhat bizarre. In conclusion, both $A$. verrucosa and $A$. fulgens are formally revalidated.

\subsection{Tetrabothrus BernhaUER, 1915 \\ Tetrabothrus laticornis (WASMANN, 1896)}

Material examined: Nepal: 1 ex., Kosi, Arun valley, S Num, 1050 m, 21.IV.1984, leg. Löbl \& Smetana (MHNG); 1 ex., Khandbari District, Arun valley at Num main bridge, 1050 m, 20.IV.1984, leg. Smetana (cAss).

Comment: This species has been recorded from central and eastern Nepal, as well as from North India (West Bengal: Darjeeling) (Assing 2006c).

\subsection{Lomechusoides TotTENHAM, 1939}

\section{Lomechusoides mongolicus (WASMANN, 1897)}

Material examined: Mongolia: 4 exs., Ulan Bator env., Zajsan, 28.V.1989, leg. Bocák (NHMB, cAss).

Comment: This species has been recorded from East Siberia, the Russian Far East, Mongolia, and North China (SMETANA 2004). 


\section{Lomechusoides penicillatus spec. nov.} (Figs 76-81)

Type material: Holotype ${ }^{\top}$ [with worker of Formica chinensis attached to the pin]: "China [18a] - S-Gansu, mts.

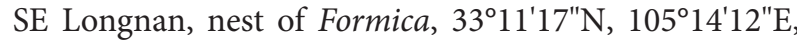
2060 m, 7.VIII.2012, V. Assing / Holotypus ơ Lomechusoides penicillatus spec. nov. det. V. Assing 2014" (cAss). Paratypes: $20^{\pi} 0^{\pi}$ [each with worker of Formica chinensis attached to the pin]: same data as holotype (cAss); 2 o $~ ㅇ$, 1 sex?: same data as holotype, but leg. Wrase (cSch, cAss).

Etymology: The specific epithet (Latin, adjective: with brushes) alludes to the pronounced tufts of golden glandular setae on the anterior segments of the abdomen.

Description: Large and robust species; body length 7.1-8.0 mm; length of forebody $3.4-3.6 \mathrm{~mm}$; width of pronotum (across posterior angles) $2.0-2.2 \mathrm{~mm}$; combined width of elytra $2.3-2.5 \mathrm{~mm}$. Coloration: head dark-brown to blackish-brown; pronotum brown to dark-brown; elytra reddish to reddish-brown; abdomen dark-reddish, with segment VI and anterior portion of segment VII more or less distinctly darker; legs darkbrown; antennae blackish-brown.

Head (Fig. 76) with deep, shallowly microreticulate, and somewhat glossy median groove; remainder of dorsal surface with pronounced microreticulation and matt; punctation relatively fine and barely noticeable in the microsculpture; pubescence short, depressed to suberect, silvery to golden, and directed anteriad. Antenna (Fig. 77) 3.4-3.7 mm long; antennomere I large; II much smaller than I and weakly oblong (length including basal portion); III club-shaped and nearly twice as long as broad; IV very weakly oblong; V-X distinctly oblong; XI coniform and apically acute, slightly more than three times as long as broad and (without basal portion) approximately as long as combined length of IX and $\mathrm{X}$; III-XI with very fine and dense, II with stouter and sparser pubescence; inner faces of IV and of anterior half of III with brush-like clusters of short erect setae in addition to the fine pubescence.

Pronotum (Fig. 76) approximately 1.6 times as broad as long and 2.2 times as broad as head, distinctly narrowed in anterior half and weakly dilated in posterior half, widest across posterior angles; lateral margins weakly sinuate in posterior half in dorsal view; lateral margins relatively weakly thickened; posterior margin strongly convex in the middle; punctation moderately sparse, distinct, and granulose; lateral margin separated from disc by longitudinal impression; disc, including anterior and posterior margins, with shallow microreticulation and somewhat glossy; lateral margins with pronounced microreticulation and matt.

Elytra (Fig. 76) slightly broader than, and nearly as long as pronotum; anteriorly with 5-6 long black setae each; posterior margin weakly sinuate near posterior angle; punctation much finer than that of pronotum; interstices with fine microreticulation. Hind wings present.

Abdomen (Fig. 78) broader than elytra, broadest at segment V; tergites II-V laterally with pronounced tufts of long golden glandular setae and in posterior halves with scattered punctures with long black setae; tergite VI with sparse setiferous punctures bearing long black setae at posterior margin, otherwise impunctate; tergites VIIVIII with micropunctation; all segments with shallow microreticulation; posterior margin of segment VIII broadly and deeply concave posteriorly, postero-lateral angles each with tuft of golden setae; posterior margin of tergite VII with palisade fringe.

$0^{*}$ : median lobe of aedeagus $1.2 \mathrm{~mm}$ long and shaped as in Figs 79-80.

+ : spermatheca as in Fig. 81.

Comparative notes: Based on the characters specified by Jászay \& Hlaváč (2013), the new species belongs to the L. strumosus group; which previously included five species: L. inflatus (ZetTerstedt, 1828), L. mongolicus, L. sibiricus (Motschulsky, 1860), L. strumosus (FAbricius, 1792), and L.teres (Eppelsheim, 1884). Among these species, L. penicillatus is most similar to L. strumosus, together with which it would key out using the key in WASMANN (1897) and from which it differs by the broader and more transverse pronotum, the more oblong preapical antennomeres, the much less thickened lateral margins of the pronotum, the more extensively glossy pronotum (L. strumosus: anterior and posterior margins with pronounced microreticulation and matt), the shorter tibiae, the much more pronounced lateral tufts of glandular setae on the abdominal segments II-V, the posteriorly much more deeply concave tergite VIII, and by the different sexual characters.

Distribution and natural history: The type locality is situated in a mountain range to the southeast of Longnan in southern Gansu province, China. All the specimens were collected from the same nest of Formica chinensis WHEELER, 1913 (Formica truncorum group) on a slope with scree, shrubs, and small trees.

\section{Acknowledgements}

My thanks are due to the colleages indicated in the material section for the loan of material from the collections under their care, in particular to Michael Schülke (Berlin) for the generous permission to retain the holotypes of Drusilla flagellata and D. palata. Munetoshi Maruyama (Fukuoka) provided helpful comments on the Pella species collected in China. Bernhard Seifert (Görlitz) identified the host ant of Lomechusoides penicillatus. Benedikt Feldmann (Münster) proof-read the manuscript. 


\section{References}

Assing, V. 2003: A review of the Himalayan species of Amaurodera (Coleoptera: Staphylinidae: Aleocharinae). - Entomological Problems 33 (1): 5-20.

Assing, V. 2005a: A revision of the Middle Asian species of Drusilla LEACH (Insecta: Coleoptera: Staphylinidae: Aleocharinae). - Entomologische Blätter $101(1)$ 43-56.

Assing, V. 2005b: On the western Palaearctic species of Drusilla LEACH, with special reference to the species of the eastern Mediterranean (Coleoptera: Staphylinidae, Aleocharinae). - Koleopterologische Rundschau 75: 111-149.

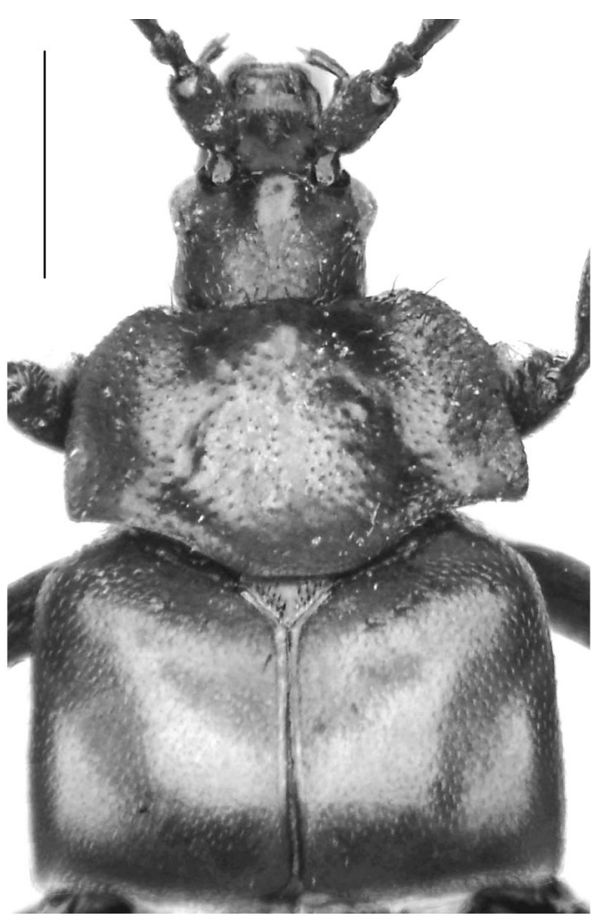

76

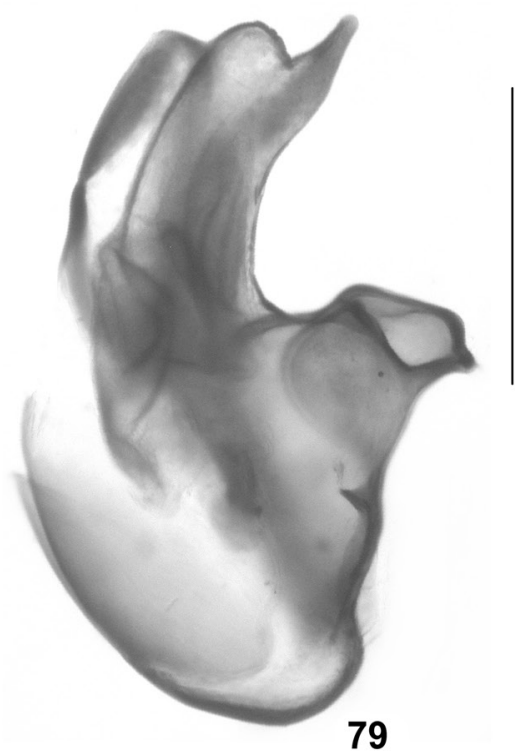

79

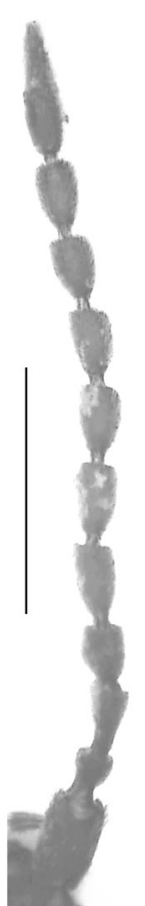

77

Assing, V. 2005c: New species and records of Staphylinidae from Tunisia (Insecta: Coleoptera). Linzer Biologische Beiträge 37 (2): 749-770.

Assing, V. 2005d: A review of the Himalayan species of Amaurodera (Coleoptera: Staphylinidae: Aleocharinae). II. New species and additional records. - Stuttgarter Beiträge zur Naturkunde Serie A (Biologie), Nr. 680: 1-12.

Assing, V. 2006a: A new species and new records of Amaurodera FAUvel from Nepal (Coleoptera: Staphylinidae, Aleocharini). - Beiträge zur Entomologie, Keltern 56: 155-160.

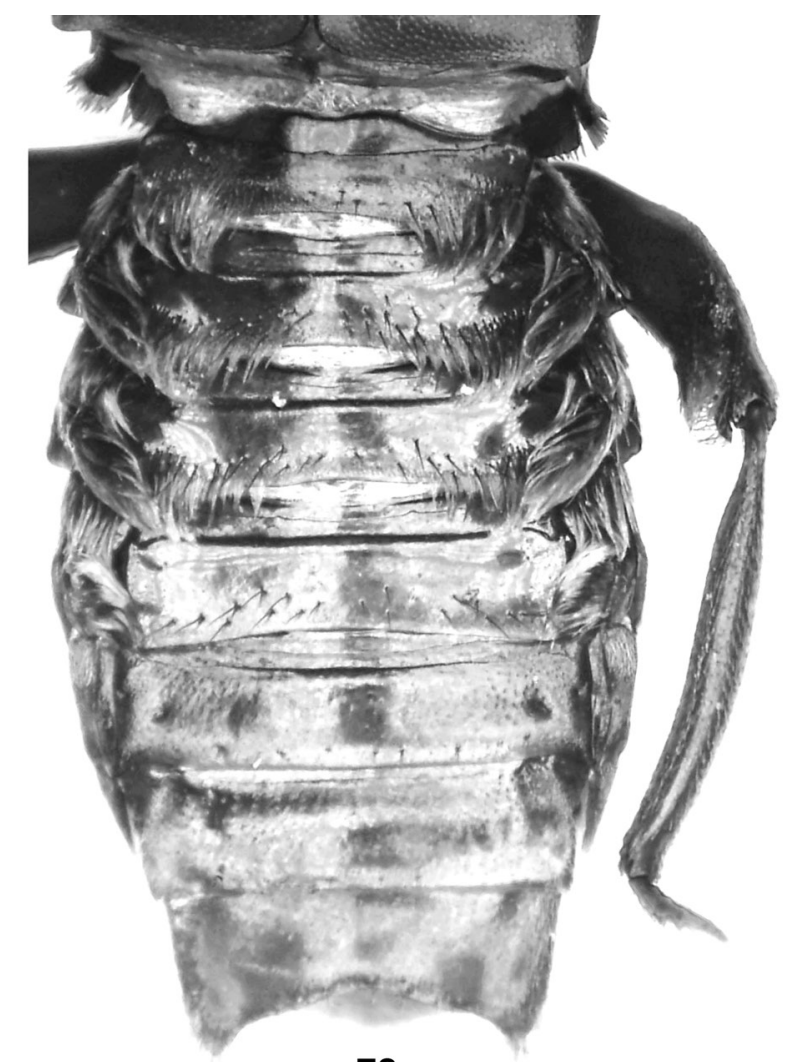

78

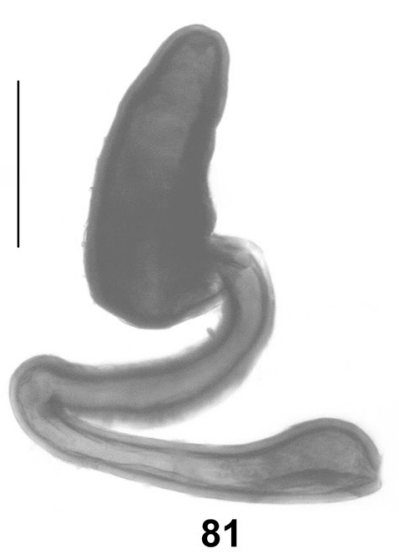

80

Figs 76-81: Lomechusoides penicillatus spec. nov.: forebody (76); antenna (77); abdomen (78); median lobe of aedeagus in lateral and in ventral view (79-80); spermatheca (81). Scale bars: 76-78: $1.0 \mathrm{~mm} ; 79-80: 0.5 \mathrm{~mm} ; 81: 0.2 \mathrm{~mm}$. 
Assing, V. 2006b: On the Italian species of Drusilla LEACH, 1819, with a note on D. taygetana Assing (Coleoptera: Staphylinidae, Aleocharinae). - Beiträge zur Entomologie, Keltern 56 (2): 281-296.

Assing, V. 2006c: On the Himalayan species of Tetrabothrus BernHAUER (Insecta: Coleoptera: Staphylinidae: Aleocharinae). - Entomological Problems 36 (1): 49-54.

Assing, V. 2008a: A revision of the Western Palaearctic and Middle Asian species of Drusilla LEACH. IV. A new species from Iran and additional records (Coleoptera: Staphylinidae, Aleocharinae, Lomechusini). - Entomologische Blätter 103/104: 51-58.

Assing, V. 2008b: Three new species of Pella Stephens from Turkey and Iraq, with a checklist of the species recorded from Turkey (Coleoptera: Staphylinidae: Aleocharinae: Lomechusini). - Linzer Biologische Beiträge 40 (1): 235-243.

Assing, V. 2009: New species and additional records of Lomechusini from the Palaearctic region (Coleoptera: Staphylinidae: Aleocharinae). - Stuttgarter Beiträge zur Naturkunde Serie A, Neue Serie 2: 201-226.

Assing, V. 2010: Two new species and additional records of Lomechusini from the Palaearctic region (Coleoptera: Staphylinidae: Aleocharinae). - Linzer Biologische Beiträge 42 (2): 1093-1104.

Assing, V. 2011: On the Staphylinidae (Coleoptera) of Iran. II. New species and additional records, with special reference to the Paederinae, Xantholinini, and Aleocharinae. - Stuttgarter Beiträge zur Naturkunde Serie A, Neue Serie 4: 137-183.

Assing, V. 2015a: On the Orphnebius fauna of the East Palaearctic region. VI. Six new species from China and Taiwan, and additional records (Coleoptera: Staphylinidae: Aleocharinae: Lomechusini). - Linzer Biologische Beiträge 47 (1): 101-125.

Assing, V. 2015b: On the Tetrabothrus fauna of China (Coleoptera: Staphylinidae: Aleocharinae: Lomechusini). - Linzer Biologische Beiträge $47(1)$ : 127-143.

Hlaváč, P.; Newton, A. F. \& Maruyama, M. 2011: World catalogue of the species of the tribe Lomechusini (Staphylinidae: Aleocharinae). - Zootaxa 3075: $1-151$.

JÁszay, T. \& HLAvÁč, P. 2013: A taxonomic revision of the myrmecophilous genus Lomechusoides TotTENHAM, 1939 (Coleoptera: Staphylinidae: Aleocharinae). Part I. Redescription of the genus, definition of species groups and the revision of the amurensis WASMANN 1897 species group. - Zootaxa 3683 (1): 65-81.

Maruyama, M. 2006: Revision of the Palearctic species of the myrmecophilous genus Pella (Coleoptera, Staphylinidae, Aleocharinae). - National Science Museum Monographs 32: 1-207.
Maruyama, M. \& Kishimoto, T. 2002a: Myrmecophilous species of Drusilla (Coleoptera, Staphylinidae, Aleocharinae) associated with Lasius (Dendrolasius) spp. (Hymenoptera, Formicidae, Formicinae) from China. Part 1. - Special Bulletin of the Japanese Society of Coleopterology 5: 227-232.

Maruyama, M. \& Kishimoto, T. 2002b: Myrmecophilous species of Drusilla (Coleoptera, Staphylinidae, Aleocharinae) associated with Lasius (Dendrolasius) spp. (Hymenoptera, Formicidae, Formicinae) from China. Part 2. - Elytra, Tokyo 30 (1): 111-118.

Motschulsky, V. DE 1845: Observations sur le musée entomologique de l'Université Impériale de Moscou. - Bulletin de la Société Impériale des Naturalistes de Moscou 18 (4): 332-388.

PACE, R. 1992: Aleocharinae della Thailandia (Coleoptera, Staphylinidae). - Bolletino del Museo Civico di Storia Naturale di Verona 16 (1989): 227-268.

PACE, R. 1993: Aleocharinae della Cina (Coleoptera, Staphylinidae). - Bolletino del Museo Civico di Storia Naturale di Verona 17 (1990): 69-126.

PACE, R. 1998: Aleocharinae della Cina: Parte IV (Coleoptera, Staphylinidae). - Revue Suisse de Zoologie 105 (4): 911-982.

PACE, R. 2006: Aleocharinae del Nepal al Naturkundemuseum di Erfurt (Insecta: Coleoptera: Staphylinidae). - In: Hartmann, M. \& Weipert, J. (eds): Biodiversität und Naturausstattung im Himalaya II. - Erfurt: Verein der Freunde und Förderer des Naturkundemuseums Erfurt e.V.: 343-408.

PACE, R. 2012: Biodiversità delle Aleocharinae della Cina: Lomechusini e Thamiaraeini (Coleoptera, Staphylinidae). - Beiträge zur Entomologie, Keltern 62 (1): 77-102.

PACE, R. 2013: Nuovo contributo alla conoscenza delle Aleocharinae del Nepal (Insecta: Coleoptera: Staphylinidae). - Vernate 32: 347-370.

Schülke, M. \& Smetana, A. (in press): Staphylinidae. In: LöвL, I. \& LöвL, D. (eds): Catalogue of Palaearctic Coleoptera. New, updated Edition. Volume 2 Hydrophiloidea - Staphylinoidea. - Brill, Leiden and Boston.

SmetanA, A. 2004: Staphylinidae, subfamily Aleocharinae, pp. 353-494. - In: Löbl, I. \& Smetana, A. (eds), Catalogue of Palaearctic Coleoptera. II. Hydrophiloidea - Histeroidea - Staphylinoidea. - Stenstrup, Apollo Books: 942 pp.

Wasmann, E. 1897: Revision der Lomechusa-Gruppe. - Deutsche Entomologische Zeitschrift 1896 (1-2): 244-256.

YAN, Z.-Q. \& LI, L.-Z. 2015: New species and additional records of Amaurodera FAUvel in southern China (Coleoptera, Staphylinidae, Aleocharinae). - Zootaxa 3931 (2): 272-278. 